\title{
„Ezt a Gyönyör tervezte veled...”
}

\section{A római villa múvelődéstörténeti jelentősége Publius Papinius Statius költészetében}

\author{
„Pleasure herself, her gentle hand, designed it with you,...” \\ The Culture-Historical Importance of the Roman Villa \\ in Publius Papinius Statius's Poetry
}

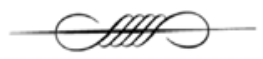

\begin{abstract}
This study is about the poetry of Publius Papinius Statius at the end of the first century AD. Statius's poetry was closely linked to the Flavian-dinasty and also to the emperor Domitianus. In this study I am going to examine Statius's collection of occasional poems, named Silvae (Forest). From this collection I choose one particular piece of work: a poem about the luxurious villa of Manilius Vopiscus at Tibur (today Tivoli, $30 \mathrm{~km}$ far from Rome, at Lazio). Now I am going to write about the possible functions of this collection as a communication form for the contemporary elite. As a social group this elite was based upon different elements, for example traditionally old noble families (like senators or knights), wealthy and talented men from another regions of the ancient Italy or from the romanized provinces of the Empire and the liberated slaves. The collected verses with the establishment of the cliental poetry offered a way for the elite to represent its wealth, taste of art, education and prestige in the roman society. The villa as a poetic motive and a real estate was able to express its owners' material aboundance and also their philosophical and literary interest. Statius's villa-poem created not only a toleranted (against Horatius's poetry) but a celebrated literary image of a lavish villa, like Pliny the Younger about his villas in Latium and Etruria in his letters.
\end{abstract}

\section{KEYWORDS}

social group, prestige, villa, poetic motive, philosophy 


\section{DOI 10.14232/belv.2018.2.1 https://doi.org/10.14232/belv.2018.2.1}

Cikkre való hivatkozás / How to cite this article: Ormos Bálint (2018): „Ezt a Gyönyör tervezte veled..." A római villa művelődéstörténeti jelentősége Publius Papinius Statius költészetében. Belvedere Meridionale 30. évf. 2. sz. 5-30. pp.

ISSN 1419-0222 (print) ISSN 2064-5929 (online, pdf)

(Creative Commons) Nevezd meg! - Így add tovább! 4.0 (CC BY-SA 4.0)

(Creative Commons) Attribution-ShareAlike 4.0 International (CC BY-SA 4.0)

www.belvedere-meridionale.hu

\section{BEVEZETÉS}

Publius Papinius Statius (Kr. u. 45-96) verseit olvasva néhány kérdés akaratlanul is felmerülhet a mindenkori olvasóban. Mitől érezhetünk valóságosnak egy irodalmi művet? A szerző hogyan képes hatni a nyelvi eszközök és az eszmei mondanivaló segítségével az érzékelésünkre és a gondolkodásunkra? Az ókorból fennmaradt irodalmi alkotások nem csupán nyelvi megformáltságuk, a beléjük helyezett filozófiai üzenet miatt, hanem a művelődés- és társadalomtörténeti háttér okán is figyelemre méltóak. A müértő, egyben élvezettel teli intellektuális tevékenység a múltban inkább a felsőbb, vagyonos és képzett társadalmi rétegekre volt jellemző elfoglaltság. Ifjabb Plinius levelezése - példának okáért - az utóbbi tevékenység egyik írásos reprezentánsa. Ifjabb Plinius műgonddal fogalmazta leveleit, így a bennük megörökített emberek és tárgyak egyben irodalmi műalkotások: portrék és érzékletes leírások. Egy ilyen leírás (ekphrasis) Plinius villájának jellemzése is, amellyel eleven képet festett egy intellektuális és vagyoni szempontból elitcsoportba tartozó személy otthonáról.

A villával kapcsolatos leírás a költészet berkeiben szintén megszületett. A vers pedig alkalmas arra, hogy metaforikus módon értelmezze a modellül szolgáló valóságot, annak szereplőit és kellékeit. S itt újabb kérdések merülnek fel: a nyelvi megformálás és a szövegkörnyezet együttesen milyen újabb tereket tárnak fel az értelmezői olvasás előtt? S mennyire voltak a fantázia termékei az irodalomban megörökített tájak és villák? A római költészetben ${ }^{2}$ ugyanis megfigyelhető a valóság megragadására való törekvés, egyfajta mimésis. ${ }^{3}$ A versbe foglalt táj és a villa emiatt több ponton kapcsolódtak a valósághoz, viszont a verssorokban megfogalmazott

\footnotetext{
${ }^{1}$ Plin. Ep. 2.17.

2 A Statiusszal kortárs Martialis (Mart. 10.4.10.) ,,emberszagú” verseket kívánt alkotni lásd Adamik 2009. 25-26.

${ }^{3}$ A mimésis fogalma (Arist. Poet. 1-4.; 9.; 22.; 25.) olyan cselekedetet jelentett, amelynek során valami hasonlóvá vált valamihez. Idővel valaminek a minél ,élethübb” visszaadása lett a mimésis funkciója lásd BENCZE 2017. 70.; SZEKERES 2012. 11-12. Cicerónál szintén előfordulnak utalások a valósághű ábrázolásra lásd Cic. De or. 2.94., 3.204.; Cic. De rep. 4.11.; Cic. Rosc. Am. 47.
} 
eszméknek rendelődtek alá. Így egy alternatív vidék, ezen belül pedig egy alternatív villa képe jött létre a művekben. A következő oldalakon a római kori, Itáliában fellelhető villával, illetve irodalmi reprezentációjával kívánok foglalkozni a Kr. u. 1. századi Statius: Erdők (Silvae) címü versgyüjteményében. A költő által, a Silvae 1. könyvének 3. versében jellemzett villát és a hozzá társított tájképet pedig a valóság és fikció egymást fedő halmazaiban kívánom megragadni.

\section{TÁRSADALMI HÁTTÉR}

Rühl $^{5}$ és Alföldy ${ }^{6}$ alapján a Kr. e. 1. század végén egy nyilvánvaló szerkezeti változás köszöntött be a kései köztárságban, azon belül is a római társadalomban. Ez a változás azonban már a Kr. e. 2. században kezdetét vette Rómának a Mediterráneumba történő expanziójával. A (városi) római előkelők a hivatali ranglétrára (cursus honorum) és az ősök szokásainak (mos maiorum) látszólagos hűségére koncentráltak. Ezek segítségével kívántak az elit tagjai alkalmazkodni és megkülönböztetni magukat. Utóbbi tényezőket viszont mindinkább a megszerzendő presztízs anyagi, politikai és kulturális szempontjai töltötték ki. A római elit mint csoport pedig átjárhatóvá vált. A Rómán kívüli helyi előkelők és a felszabadított, egykori rabszolgák ugyanis megtapasztalták a hatalomban és státuszban rejlő előnyt azáltal, hogy társadalmi kapcsolatokra és anyagi jólétre tettek szert. A későbbiekben mindez együtt járt a szabadidő (otium) elitista szemléletű kialakításával, amely utat nyitott a nyilvános én-formáláshoz (self-fashioning). A leggyakoribb és legjelentősebb változás bizonyosan az önmegmutatás (self-display) új módja volt, amely az anyagi jóléten alapult. Az elit (a régi és az új) társadalmi rétege mellett a növekvő ,,intellektuális lét” is figyelmet érdemel. Ez nem csupán a város közeli villák irodalmi stilizálásában nyilvánult meg, amelyek a művelődés vidékeiként funkcionáltak. A magántermészetű irodalmi elfoglaltságokra szintén alkalmazták ezt az elvet, így a villák és az irodalom az otium, továbbá a személyes presztízs kifejezésére egyaránt szolgáltak. Ezek az irodalmi, illetve kommunikációs stratégiák első ízben Cicerónál (Kr. e. 106-43) váltak nyilvánvalóvá. Cicero szinte teljes mértékben kimerítette az irodalmi eszköztárat pozíciói és érdemei kifejezésére. Ugyanezek érvényesek az őt követő Ifjabb Plinius (Kr. u. 61-113) esetében is, aki főleg a levelet használta az otium (az intellektuális természetű szabadidős tevékenység) és a negotium (hivatalos jellegű elfoglaltság vagy munkavégzés) kifejezésére és az utóbbiakra történő reflektálás médiumaként. Ezek az irodalmi stratégiák, tehát a levélírás, a szónoki beszédek megfogalmazása, értekezések írása vagy a költészet művelése

\footnotetext{
${ }^{4}$ A képzőművészeti és irodalmi ábrázolások egyaránt tekinthetőek a mimésis megnyilvánulásának, sőt: e kétféle ábrázolás szintézisének is elkönyvelhető. Az irodalmi szemléletesség (evidentia) hatékonysága az emberi tapasztalaton nyugvó valószínűség reprodukálhatóságán, továbbmenve pedig az író fogalmazókészségén múlik. Az írói szemléltetés során folyamatosnak tekinthető a reflexió a modellre, amely maga a valóság. A szemléletesség összetevői azonban költőnként eltérőek és egyben egyediek. A szemléletesség céljára hasznosított költői kép viszont képes átlépni az anyagi és a szellemi határát és ebbéli tulajdonságában exemplum jelleget ölt. Figyelemreméltó a Rhet. Her. 4.39. szöveghelye, amely szerint a festészet néma poiésis, a poiésis pedig hangos festészet. Mindkettő mimésist végez, ezért a NAGYILLÉS által elemzett Lucanus (Kr. u. 39-65) - munkássága alapján - egyszerre tekinthető festőnek, költőnek és szónoknak lásd NAGYILLÉs 2012. 38-39., 40., 44., 58-59.

5 RÜHL 2015. 91-93.

${ }^{6}$ Alföldy 2002. 88-95.
} 
különösen hatásosak voltak népszerűsítő eszközökként, mivel létezett egy olyan közönség, amely méltányolta ezeket. A legtöbb esetben ez a hallgatóság ugyanabba vagy a közvetlenül egymással szomszédos társadalmi csoportok egyikébe tartozott, így szolgáltatva egy közös terepet a kommunikációhoz. Olyan szöveggyüjtemények és szövegtípusok számára, mint amilyen Ifjabb Plinius levelezési anyaga, ${ }^{7}$ egyaránt alkalmasak voltak e stratégiák az intellektuális inkluzivitás és exkluzivitás prezentálására a feladó és a címzett között. Emiatt nem számított, hogy e szövegek fogadtatása akár egy csoporton belül, egy bizonyos körre korlátozódott. A szövegekben megnevezett személyek közötti összeköttetés ugyanis a szövegek összegyüjtött kiadása alapján már egy megfelelő ,,közösségi viszonyt” hozott létre. A szövegek e gyüjteménye nem csupán a római társadalomba engedett bepillantást a horizontális és vertikális társadalmi összeköttetés mentén. Ez a fajta szöveg-corpus arra is alkalmas volt, hogy megcímezze ezeket a személyeket az individuális szövegekben és így hangsúlyozza az egyén helyzetét egy koordinált hálózatban.

Erre jó példa a Silvae 1. könyvének bevezetője. Ebben az előszóban Statius az 1. könyvet Lucius Arruntius Stellának ajánlotta, aki Kr. u. 101-ben töltötte be a consul suffectus tisztet, emellett Martialis pártfogója is volt. A költőt és a jó nevű pártfogót mintegy egyenrangúvá tette az a szerzői megjegyzés, amely szerint közösen hódoltak az emelkedett tanulmányoknak, azaz a költészetnek. A további megnevezett személyek közül Cordinus Rutilius Gallicus (kb. Kr. u. 28-92) lovagrendủ személy volt, de pályafutása során betöltötte a praetor, procunsuli rangú legatus, praefectus urbis és a consuli tiszteket. Claudius Etruscus ${ }^{8}$ egy libertinus és egy patríciusnő fia volt, akinek az apja több császár udvarában magas rangú gazdasági tisztséget töltött be. A címzetteknek ez a sora is kellően szemlélteti a római elitnek a Kr. u. 1. századra jellemző heterogenitását, ${ }^{9}$ illetve azt a kiszélesedett platformot, amely lehetőséget biztosított az elit-kultúra bemutatására. Statius ráadásul ténylegesen kiadásra szánta a Silvae verseit és számított az olvasók reflexiójára. A versek címzettjei származásuk, vagyonuk vagy hivatali tevékenységük okán nagy presztízzsel és valószínüleg jelentős kapcsolati tőkével is rendelkeztek. Mindez pedig magához vonzotta az egyéb elit körökbe tartozó olvasók táborát. Az előszó és a ténylegesen megcímzett versek a korabeli elit jól ismert képviselőiről szóltak, amelynek okán az elit-olvasók otthonosan mozoghattak a versek szöveg-kontextusában.

\footnotetext{
' Ifjabb Plinius kortársakkal szembeni állásfoglalása levezethető a pozitív hangvételü ,,portré-levelekböl” (pl. Plin. Ep. 1.14.; 7.25.; 7.31.). Ezekben a levelekben a szerző leírta az aktuális címzettnek a harmadik fél (politikai, életrajzi és kulturális) érdemeit, erényeit és jellegzetességeit, majd beajánlotta őt a címzettnek. Nyilvánvaló, hogy a kortársakról alkotott ítélet nem csupán bennfentes tudást igényelt, hanem társadalmi pozíciót is, amely legalább azonos, ha nem magasabb volt a feladó és a címzett részéről a harmadik féllel szemben. Az ismeretség és a társadalmi helyzet látszottak tehát garantálni - RüHL felfogásában - a hitelesnek és elfogadhatónak tűnő kijelentést a harmadik féllel kapcsolatban a címzett számára lásd RüHL 2015. 93.

${ }^{8}$ Akinek a fürdőjét Mart. 6.42. is megörökítette.

${ }^{9}$ Ez a fajta heterogenitás azonban már a Kr. e. 2. században képviseltette magát a kulturális és vagyoni elit csoportján belül. Gondoljunk csak a Scipio-kör tagjaira. Panaitios filozófus Rhodosról származott, a történetíró Polybios hadifogolyként került görög földről Rómába, a drámaíró Terentius Afer pedig feltehetőleg felszabadított rabszolga volt Karthágóból, a szatíra-költő Lucilius pedig lovagi ranggal rendelkezett és vidéki környezetből, a Campania és Latium határán elterülő Suessából érkezett a Scipio-körbe lásd ADAMIK 2009. 136-137., 155.; DrOUGOU 2001. 41-42.; INwood 2000. 226. A Kr. e. 2-1. században élő Lucullus pedig egy ízben azt állította, hogy Tusculumban levő villája szomszédságában egy felszabadított rabszolgának és egy római lovagnak is voltak házai, amelyek fényưzésükben vetekedtek az ő ingatlanával lásd Cic. Leg. 3.30.
} 
Rühl ${ }^{10}$ a római társadalomban bekövetkező kulturális változások szemléltetése érdekében Jurij Lotman: A szemioszféráról, Roland Posner: Kultursemiotik, illetve Andrew Wallace-Hadrill: Rome's Cultural Revolution című értekezéseit használta fel az elméleti keretek kialakításához. Ezek az elméleti elképzelések a kultúrát mint szemiotikai rendszerek hierarchiáját interpretálják, amely rendszerek bizonyos műalkotásokat hoznak létre, azaz anyagi termékeket a fogalom legtágabb értelmében, ideértve az irodalmi műveket is. A társadalom bizonyos tagjai bizonyos kódokon keresztül érnek el bizonyos anyagi termékeket. Minél központibb és jelentősebb egy műalkotás a társadalom (vagy egy része) számára, s minél inkább használatban van, annál rangosabb. Lotman kiemelte a szemioszféra fogalmát, amelyet koncentrikusan elrendezettnek kell elképzelni. Ez megmagyarázza, hogy a más kultúrából származó kódok - amelyek elsőre külsődlegeseknek tünnek - miért adaptálódnak fokozatosan, amíg végül befogadást nyernek. A külső kódok beékelődéséből és szemiotikájából fakadó dinamika pedig tisztázza a változásokat a kulturális jelenségekben. Nem csupán a tárgyak és a szövegek szerepe ment át tehát változáson, hanem az emberek elit-csoportja is megváltozott, amely e jeleket és kódokat használta; úgy is mondhatjuk, hogy gyarapodtak. Az előkelők tábora ugyanis egyre inkább az eltérő származású, de jómódú és feltörekvő személyek soraiból egészült ki. Az olyan kódok, mint a luxuria (fényüzés) és otium így egyre gyakoribbakká és rangosabbakká váltak. Amint pedig egy adott kód központivá lesz - érvel Rühl - a társadalom egy kiszélesített rétege veszi használatba. E réteg számára pedig elismertté és egyben vonzóvá is válik. Minél gyakrabban használták a múltban ezt a kódot a kultúra felhasználói, annál mintaszerübbé vált és annál inkább másolták. Így a korábban mellékesnek számító jegy ,,fósodorbeli” jelenséggé változott. A megkülönbözetett identitásra épülő társadalmi csoport emiatt alkalmasabbá vált arra, hogy adaptáljon és feldolgozzon külsődleges, görög eredetű szövegeket, műfajokat és stílusokat. A Kr. e. 1. század végén már nem volt elég luxus-javakat birtokolni és fitogtatni azért, hogy valaki kitűnhessen a tömegből. Ez a sokaság (pl.: gyorsan vagyonosodó libertinusok, feltörekvő homo novusok, s ezeken belül kereskedők [mercatores], üzletemberek [negotiatores]) már megengedhetett maga is drága étkészletet, falképeket vagy ínyenc étkezéseket. S emiatt a kulturális elit kódja is átállt a műalkotásoknak, továbbá a luxuria és otium jelenségeinek az együttes reflexiójára és finomítására, amelyeket az irodalom kapcsolt egybe. Egy disztingvált, elit-körökbe tartozó római (mint amilyen Ifjabb Plinius is volt), maga is számolt a luxuria és az otium értelmezésével és kommunikálhatóságával - vagy egy hivatásos írót bízott meg $^{11}$ vele. Az egyén számára - az elit-csoporton belül használva ezt a kódot - a kód specifikus irányba történő fenntartása és kibővítése lett a kiemelkedésre és az exkluzivitásra szánt eszköz.

Ha az elit-kultúra ugyanakkor a rétegkultúra terminussal is jellemezhető, akkor azzal is számolni kell, hogy nem csupán a luxus-tárgyakat, hanem az irodalom termékeit is átveszik idővel az elit-kultúrán kívül eső társadalmi rétegek és saját igényeik szerint használják fel. Ebben az esetben az elit megkülönböztetett identitásának a kulcseleme többé már nem töltheti be maradéktalanul eredeti funkcióját. Egy dinamikus folyamatról lévén szó, az elitnek újból meg kell határoznia és ki kell dolgoznia, hogy mely kulturális javakból építheti fel az identitását. Méghozzá egészen addig, amíg az eliten kívül eső rétegek át nem emelik ezeket az elemeket,

\footnotetext{
${ }^{10}$ RÜHL 2015. 95-96.

${ }^{11}$ Mart. 7.3. A költőnél e gyakorlat már a gúny és irónia tárgyát képezte.
} 
újraindítván az identitás-képzést. Lotman ${ }^{12}$ maga is felhívta a figyelmet arra, hogy miután egy új kulturális elem bekerül a központi struktúrába, az nem marad többé statikus. Ha pedig a kulturális jegy újonnan értelmezett műalkotásokat generál, ezeknek előbb variánsai, majd egymástól eltérő változatai jönnek létre. Ezek pedig a társadalom több rétegéhez is eljutnak, nem csupán

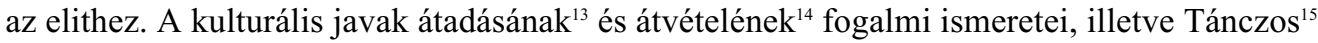
megállapításai alapján kijelenthető e javak áramlása a társadalmi csoportok között. A kulturális javak így az újítás, a módosítás erejével hatnak, majd maguk után vonják az adaptációt és a szelekciót is. Habár az átvételnek és az átadásnak egyaránt lehetnek társadalmi, gazdasági, tudati feltételei és esetleges korlátai. Minderre az egyik legjobb antik irodalmi példa a Nero (uralk.: Kr. u. 54-68) korában élő Petronius ${ }^{16}$ hőse, Trimalchio, a megtollasodott libertinus. Trimalchio hiányos irodalmi müveltsége és a könyvek iránti gyüjtőszenvedélye együttesen váltak a felszínes reprezentáció és a visszatetsző nagyzolás kellékeivé Petronius paródiájában.

Ahogy a régi előkelők ${ }^{17}$ érintkezésbe léptek az új típusú előkelőkkel, úgy utóbbi csoport származása, kapcsolati tőkéje és anyagi érdekeltsége révén az alatta levő rétegekkel érintkezett. Az előrehaladó urbanizáció, a birodalmi mértékű szervezettség és egységesítés révén az egyes kulturális javak egyre inkább elterjedtek, ${ }^{18}$ majd pedig a közművelődés elemeivé váltak. Ezeknek az ismereteknek a mélysége és minősége azonban különbözött az eltérő társadalmi háttérrel rendelkező csoportok és személyek között. A professzionalizmus így megszokottá és megfizethetővé, rosszabb esetben megunttá vagy silánnyá változott. A könyv, könyvkiadás vagy az irodalom kommerciális jellegére Martialis ${ }^{19}$ több epigrammájában némi önirónival füszerezve hívta fel a figyelmet. Az aranykor költői: Catullus $^{20}$ és Horatius, ${ }^{21}$ vagy a Nero-korabeli Persius, ${ }^{22} \mathrm{~s}$ később a Flavius-kori Martialis, ${ }^{23}$ majd utóbb Iuvenalis ${ }^{24}$ és Ifjabb Plinius ${ }^{25}$ egyaránt utaltak arra, hogy a szavalatok, nyilvános

${ }^{12}$ Lotman 2001. 186.

${ }^{13}$ MNL 1977. 162-163.

${ }^{14}$ MNL 1977. 170-171.

15 TÁnCZOS 2011.

${ }^{16}$ Petr. Sat. 53-56.; 59. Trimalchiónak ugyan volt görög és latin könyvtára, azonban összekeverte az Iliász és az Odüsszeia elemeit más, görög mitológiai részletekkel. A lakomán elhangzó, irodalommal és filozófiával kapcsolatos elmélkedések egyrészt egy szintre kerültek a különféle, meghökkentő ételek mutatványával. Másrészt a rögtönözöttnek tűnő versekben a szerző rezonőrként szólalt meg, azonban a kritikus és elgondolkodtató verssorok hatástalanok maradtak a lakoma közönségére, amíg az irodalmi mű felolvasása és elszavalása pedig kétnyelvü (görög-latin) kakofóniába torkollott.

${ }^{17}$ A Kr. e. 2. században olyan államférfiak és hadvezérek számára, mint amilyen Ifjabb Scipio Africanus (Kr. e. 185/4-129) vagy Gaius Laelius Sapiens (kb. Kr. e. 190-123 előtt) fontos volt, hogy kulturális-baráti kört hozzanak létre.

${ }^{18}$ Vö. Hor. Ep. 1.20. és Mart. 6.60. [61.]; 7.88.; 9.84. Ezekben a versekben Horatius és Martialis arról tudósítottak, hogy a birodalom más tájaira is eljuthatott a költészetük.

${ }^{19}$ Mart. 1.2.; 1.117.; 3.2.; 3.82.; 4.72.; 5.6.; 5.78.; 7.12.; 10.48.; 11.108.; 13.3.

${ }^{20}$ Catul. 14.; 22.; 50.

${ }^{21}$ Hor. Ep. 1.19.; 2.3.366-390.; Hor. Sat. 2.6.60-79.

${ }^{22}$ Pers. 1.1-62.

${ }^{23}$ Mart. 3.45.; 3.50.

${ }^{24}$ Juv. 11.60-76., 136-182.

${ }^{25}$ Plin. Ep. 1.13.; 3.1.; 3.18.; 6.15.; 9.36. 
és magánjellegű felolvasások és az étkezések közbeni társalgás bizonyos mértékben fárasztó társadalmi kötelezettségekké merevedtek vagy tobzódó látvány- és hangelemekkel telítődtek. $\mathrm{S}$ az ilyen alkalmak időnként pont a fonákságuk révén váltak egy-egy irodalmi mű témájává. Utóbbi müvekben helyet kapott a dilettantizmus, ízléstelenség, elfajzott erkölcsök, versengés, utánzás és a becsvágy kritikája is, illetve az alig leplezett büszkeség a saját szerzői vagy előadói sikerélmény felett. Mindazonáltal a megfelelő egzisztenciával rendelkező entellektüelek a későbbiekben is vágytak arra, hogy a tömegtől elkülönülve, saját ízlésvilágukat fenntartsák. A kapcsolati hálózat szintén fontos maradt. S a kommersztől történő elhatárolódás megfelelő módjaiként szolgálhattak a meghittség, bensőségesség, szelekció, intimitás, professzionalizmus és a józan keretek közt maradó fesztelenség a kifinomult, egyben kedélyes kultúrát magukénak vallók csoportján belül. A kulturális átvétel nyilvánvaló következményei tehát arra sarkallták az elitet, hogy a korábbi kulturális javak vagy kódok helyett újakat sajátítsanak el, amelyek megkülönböztetik őket a többiektől. Mindazonáltal az elit is átadhatta magát az alacsonyabb rendü $\mathrm{s}$ inkább a tömegigényeket kiszolgáló szórakozási formáknak. A Circus Maximusban ${ }^{26}$ külön ülőhelye volt a szenátoroknak és a lovagoknak, ahogy a Colosseumban is rang és nem szerint különítették el a nézőket. S ugyanúgy érdeklődhetett egy tragikus darab iránt az egyszeri római polgár is, amelyet megtekinthetett a nagybefogadó képességű színházak egyikében. Az elit és (a kifinomultság iránt érdeklődést mutató és a populárisabb kulturális javakat birtokolni képes, de már) az eliten kívül eső személy egyaránt élhetett a ki- és betekintés nyújtotta lehetőséggel. De ugyanazokat a kulturális javakat az elit és az eliten kívül esők más és másféle módon hasznosították.

\section{KulturÁlis hátTÉr}

Marzano, ${ }^{27}$ Mielsch $^{28}$ és Newlands ${ }^{29}$ a Kr. e. 2. századra tették a villa fogalmában bekövetkező eszmei váltást, amelynek következtében a villa többé nem pusztán gazdasági egységnek számított. Ezt a váltást egyrészt Scipio Africanushoz kötötték, aki Kr. e. 184-ben politikai kegyvesztettsége miatt vonult vissza a campaniai partvidéken, Liternumban levő villájába ${ }^{30} \mathrm{~S}$ mindehhez hozzájárultak még a városi kultúra, a városias luxus mind nagyobb térhódításai is a vidéki ingatlanokban.

\footnotetext{
${ }^{26}$ HuMPhrey 1986. 102.

${ }^{27}$ Marzano 2007. 85., 87., 91.

${ }^{28}$ MielsCH 1987. 7., 37.

${ }^{29}$ NeWLands 2002. 122-123.

${ }^{30}$ Mindehhez lásd Liv. 38.52.1. közlését is. Seneca egyik levelében leírta, hogyan látogatta meg Scipio villáját. Seneca csupán futólag említette meg, hogy a villához tartozott egy fallal kerített erdő, egy nagy víztározó, továbbá bástyák, ezután rátért Scipio kamra nagyságú, félhomályos fürdőszobájának a részletes jellemzésére lásd Sen. Ep. 86.1-13. A levél kapcsán érdemes elgondolkodni azon, hogy Seneca milyen kevés mondandót szánt a villa többi részének a leírására. Nem tudható biztosan, hogy Scipio halála (Kr. e. 183) és Seneca saját kora (Kr. e. 4-Kr. u. 65) között mennyire alakították át a villát. Suetonius közléseiből tudjuk, hogy nem volt ismeretlen a rómaiak számára, hogy egy-egy fontosabb személyiség otthonát úgy őrizték meg az utókornak, ahogyan az illető után maradt halálát követően lásd Suet. Aug. 6. és Vesp. 2. Feltehető ezért, hogy Seneca Scipio otthonát annak viszonylagos érintetlenségében láthatta még. Emiatt ronthatott volna a Luciliusnak szánt filozófiai-etikai lecke hatásfokán, ha Seneca leírásából a villának egy olyan képe rajzolódik ki, amely arra mutatott volna rá, hogy Scipio visszavonultságában tekintélyes és igényesen kialakított ingatlannal rendelkezett.
} 
Marzano $^{31}$ nyomán, Scipio korát követően, a villa mindinkább összekapcsolódott az otiummal, azaz a kényelmes élettel és szabadidővel. Az eredetileg földművelésre alapult gazdaságban pedig egyre inkább feltűntek a választékosabb termelőegységek ${ }^{32}$ vagy olyan létesítmények, ${ }^{33}$ amelyek már nem a gazdasági, hanem az intellektuális „,termelést” segítették elő. Utóbbiak egyaránt szolgálták az egyéni élvezetet és hatásosan fitogtatták a tulajdonos jólétét, műveltségét és befolyását. A vidéki ház mint helyszín az elit számára emiatt elvált eredeti, mezőgazdasági kontextusától. Ugyan maradtak fenn egyszerübb és inkább gazdasági jellegű villák is, de a tehetősebbek - ha módjukban állt - igyekeztek kedélyes vidéki otthonokat berendezni.

Az otium-villa, azaz leginkább a kikapcsolódásnak és gyönyörködtetésnek szentelt villa konstrukcióját Höcker ${ }^{34}$ Ifjabb Plinius két villa-levele, ${ }^{35}$ illetve építészeti és kulturális motívumok alapján alkotta meg. A római alapelv, azaz a természet kultúra által történő meghódítása az otium-villa esetében kiterjedt formában manifesztálódott. Az otium-villa kedvelt elterjedési helyszínének számított mindenekelőtt a Róma körüli dombság, (amely azonban egy napi útra elérhető maradt) távolabb Latium és Campania déli részének partjai, úgymint a nagyobb északi és közép-itáliai tavak partvidékei.

Seneca $^{36}$ egy levele alapján a villa-visszavonultság-tanulmányoknak szentelt szabadidő viszont nem mindig alkottak egymással szoros egységet. A Seneca által körvonalazható etikai probléma azonban rámutat arra is, hogy egy tehetős római nem feltétlenül a tanulmányok helyszíneként tekintett a kényelmes villára. A villában folytatott tudós szabadidő vagy éppenséggel az intellektuális elmélyedésre berendezett villa így szintén etikai, illetve irodalmi konstrukcióknak hatnak. Más szavakkal: általánosan nem jelenthető ki, hogy minden, igényesen kialakított római villa maga után vonta az emelkedett intellektuális légkört. A római társadalomban bekövetkező változások, amelyek együtt jártak a kifinomult művelődés, esztétikai élvezet, urbánus trendek és a vagyonosodás térhódításaival, nem egy mechanikus fejlődési ívet jártak be, amelynek eredményeképpen teljes mértékben elválaszthatatlan kapcsolatba kerültek volna egymással. Még Cicero $^{37}$ sem tekintett mindig villájára az elmélkedés helyszíneként, hanem olyan ingatlanra,

\footnotetext{
${ }^{31}$ MarZano 2007. 76-78.
}

${ }^{32}$ Varro az igényes madártenyésztéssel kapcsolatban is kifejtette a gondolatait lásd Var. $r$. $r$. 3.5.1-17. A madártenyészet lehetett gazdasági egység vagy a szórakoztatást szolgáló, rafináltan felépített és berendezett locus amoenus. Columella megjegyezte, hogy a vadállatok nem csupán kitűnő fogások alapanyagai lehettek, hanem a szemet is gyönyörködtethették, ezért a gazda szállása mellett kellett elhelyezni a vadaskertet (vivarium) lásd Col. 9. praef.

${ }^{33}$ Példának okáért a könyvtár, amelyet Cicero tusculumi villájában, illetve római, antiumi, cumaei, formiaei és puteoli ingatlanaiban is létesített. A villa könyvtárát Cicero előszeretettel díszítette szobrokkal és falfestményekkel. A villakönyvtár így együttesen volt a magántanulmányoknak szentelt tér, társasági helyszín és szellemi mühely lásd ACÉL 2012. 44.

${ }^{34}$ HÖCKER 2002. 216-218.

${ }^{35}$ Plin. Ep. 2.17.; 5.6.

${ }^{36}$ Sen. Ep. 55.1-8. Seneca levele arról tájékoztat, hogy a szerző Scipio Africanus villája mellett Servilius Vatia, egy praetori tisztséget betöltött személy házát is megtekintette Baiae mellett. Seneca felidézte, hogy a római közvélemény akkoriban irigyelte Vatiát, amikor a Tiberius (uralk.: Kr. u. 14-37) uralma alatt elkövetett túlkapások idején ő megengedhette magának, hogy visszavonuljon vidéki villájába és a nyugodt életnek szentelhesse magát. Seneca azonban úgy gondolta, hogy Vatia inkább eltemette magát villájában, ideje pedig jórészt haszontalanul telt. Seneca az erkölcsi fejtegetés mellett, azonban nem felejtette el kiemelni a villa előnyös fekvését, figyelemreméltó grottáit, platánligetét a csatornával és hosszabb tartózkodásra való alkalmasságát.

${ }^{37}$ Cic. Fam. 16.18. Cicero említést tett a tusculumi villájában található virágoskertből származó haszonra. Cicero úgy írt erről a villabeli kertről, mint amely jelentékeny tőkét jövedelmezett annak bérbeadásából vagy termékeinek közvetlen eladásából lásd MARZANO 2007. 74-75. 
amely az anyagi haszon letéteményese volt. Ezzel pedig visszakanyarodunk az itáliai villa legkorábbról fennmaradt, Cato-féle koncepciójára, ${ }^{38}$ amely szerint a villának egy rentábilis és jövedelmező mezőgazdasági vállalkozásként kellett funkcionálnia. De ha inkább a kényelmet és a luxust élvezte egy római villa-tulajdonos ${ }^{39}$ akkor valószínüsíthetően meg is tette, bár a társadalmi normáknak ${ }^{40}$ még így is meg kellett (legalább látszólagosan) felelnie. Mindenesetre inkább azoknak az entellektüeleknek ${ }^{41}$ a rosszallása visszhangzott az irodalmi diskurzusokban, akik erényességet kívántak belevetíteni a kifinomult gazdagságba. Ezt némileg saját, fényűző jólétük ellensúlyozása és a képzett, vagyonos, emellett kötelességtudó „,polgár-ideál” propagálása érdekében is tették. Gyakorlatuk épp arra mutatott rá, hogy az idealizált intellektuális szabadidő mellett létezett egy jóval prózaibb kikapcsolódási forma. Ez pedig ha , kötelezően ” és ,,erkölcsileg” elitélendő volt, de gyakorlati létjogosultságot nyert a római társadalomban.

A vidéki tartózkodással és villával kapcsolatos morális eszmefuttatások tehát az Augustus-kor (uralk.: Kr. e. $27-K r$. u. 14) alatt ${ }^{42}$ és azt követően ${ }^{43}$ sem évültek el. Albrecht ${ }^{44}$ szerint Statius költészete épp arra mutatott rá, hogyan tükröződhetett a vagyonos római magánember életérzése az elegáns villa épületeiben. Statius művészetében ugyanis a villa kertjeivel és szobraival az élet alkotórészének számított.

Newlands ${ }^{45}$ megállapítása szerint Statius a villa-költészettel merészen beemelt egy következetlenségekkel telített társadalmi jelenséget a konzervatív irodalomba. A Kr. u. 1. század végén emiatt a vidéki villa messzemenően magában foglalta a jóléttel, társadalmi helyzettel és művészi ízléssel kapcsolatos elképzelések diffúzióját. A villa emiatt a fényűzés kiemelkedő szimbólumának számít Statius verseiben. A drága díszítés és a kendőzetlen építészeti hivalkodás túlnyomóan pozitívnak és csodásnak mutatták be a villa jellegzetességeit. Statius pedig megtalálta a villában azt az erőteljes költői képet, amely kifejező módon jelenítette meg a Kr. u. 1. század végi társadalmi feszültségeket. Szembehelyezkedve a római, azon belül az Augustus-kori erkölcsi diskurzusok kánonjával, Statius villa-versei ${ }^{46}$ provokatívnak számítottak a fényűzés nyílt jóváhagyásával. A magánépítészet, amely gyakori céltáblája volt az Augustus-kori elődök kétes erkölcsösségének, ${ }^{47}$

${ }^{38}$ Cato Agr: 1.1-5.

${ }^{39}$ Mart. 6.43.; 12.18.

${ }^{40}$ Vö. Gel. 4.12.1-3. és Plin. Nat. 18.32. A császárkori szerzők egyrészt a kuriózum, másrészt a negatívnak tartott jelen szemléltetése miatt ellenpéldákat hoztak fel a múltból. Gellius szerint censori büntetés járt a földek elhanyagolásáért, megállapításai során pedig Idősebb Catóra hivatkozott. Idősebb Plinius szintén feljegyezte, hogy Lucullus (Kr. e. 117-57/56) büntetést kapott, mivel háza (valószínűleg lakóhelyként szolgáló villa-épülete) nélkülözte a művelés alá vont földterületet. Lucullus építményeiről lásd Var. r. r. 1.2.10.; 1.13.7.; 3.4.3.; 3.5.8.; 3.17.9.

${ }^{41}$ Vö. Col. 1.63.1-4. és Var. $r$ r $r$. 3.2.10. A Cicero munkásságát követő Augustus-kori irodalomban a magánházak ambiciózus építtetőjének a képe alaptípussá vált a római irodalmi diskurzusban (Hor. Od. 2.15.1-2., 14-15.; 2.18.19-26; ;erg. G. 2.461-463.) lásd NEWLANDS 2002. 123-125.

${ }^{42}$ Vö. Hor. Ep. 1.10.; 1.14.; Hor. Sat. 2.6. és Var. $r$. r. 2.1.1-3.; 3.2.3-6.

${ }^{43}$ Vö. Col. 1. praef. 15-18. és Mart. 3.58.

${ }^{44}$ Albrecht 2004. 746.

${ }^{45}$ NeWLANDS 2002. 125-126.

${ }^{46}$ Stat. Silv. 1.3.; 2.2.

${ }^{47}$ Augustus háztartásának a felszerelését és bútorait inkább az egyszerűség jellemezte. Suetonius szerint bútorai nem állották volna meg a helyüket egy tehetősebb polgár házában. Otthonában nővére, felesége vagy unokája által készített házi ruhában járt. Időnként azonban azzal vádolták, hogy rajongott a drága bútorokért és a korinthoszi fémedényekért. Suetonius közlése alapján pedig több gáláns és tisztességtelen kalandja is volt lásd Suet. Aug. 68-70.; 71.1. Horatius szerint pedig a szerénység hangoztatása csak költői póz volt és azt is kimondta, hogy a kis vagyonnál mégis jobb volt a nagyobb, a fényes palota pedig hírnevet és elismerést jelentett tulajdonosa számára lásd Hor. Ep. 1.15.42-46. 
új szerepre tett szert Statiusnál mint a magasröptű vágyak kifejeződése. A villa-versek tehát hozzájárultak és elő is segítették a fényűzéssel kapcsolatos attitűdök megváltozását. Mindezek következtében még merészebb módon ugyan, de újra meghatározásra került a fényüzés fogalma. Méghozzá olyan kontextusban mint az erény elérésére kínálkozó lehetőség. Statius a villaköltészetben a fényüzést nem az erkölcsi hanyatlás jeleként, hanem a morális erény és a filozófiai minőség alapvető összetevőjeként ünnepelte. A gazdagság, a technológia forrásai, a természet átalakítása, hogy szolgálja az élvezeteket, továbbá a nem öncélúnak láttatott jólét mind-mind azt jelentették, hogy általuk a tulajdonos szabadon müvelhette a költészetet és a filozófiát. Statius költészetében a villa a korábbiakhoz képest nagyobb hangsúllyal öltötte magára az intellektuális lét komplex elképzelését. Az építészeti és irodalmi találékonyság ennek következtében egymást egészítették ki és egyben hirdették, hogy a villa-vers a Flavius-kor fontos műfajává nőtte ki magát.

\section{KöLTŐ ÉS MÜVE}

Rühl ${ }^{48}$ alapján az irodalom kora császárkori professzionalizálódása egyaránt maga után vonta, hogy az irodalom produktumai (pl. a versek) a címzettek önreprezentációját szolgáló, ,,megrendelhető” termékekké váltak. Mindez tagadhatatlanul összefüggött az alkalmi jelleggel. Az olyan költők, mint Martialis és Statius hivatásos költőkként is tevékenykedtek, mivel megkapták az ellenszolgáltatást a tőlük megrendelt (vagy legalábbis elvárt) munkákért. Ezt a fajta professzionalizálódást lehet úgy is tekinteni, amelyet bizonyos területeken intézményesítettek, például a költői versenyek kapcsán Domitianus uralma alatt. Különösen a presztízs hagyományos formái és a fényűzés hivalkodó megjelenítése mellett, ez a típusú irodalom arra is lehetőséget nyújtott Róma kulturális elitjének, hogy megkülönböztesse magát saját társadalmi csoportja egyéb tagjaitól. Statius esetében a költő szintén hozzátartozott (attól függően, hogy a szerzőnek milyen volt a tényleges társadalmi és magántermészetü viszonya a versek címzettjeivel) az általa leírt személyek exkluzív köréhez. A szerző az irodalmi stílust és struktúrát pedig félreérthetetlenül adott címzettekhez igazította. Statius legtöbb címzettjéhez íródott verse tehát egy újabb lehetőséget biztosított, hogy a megszólítottak tekintélyes előnyeiket még inkább fitogtathassák. Albrecht ${ }^{49}$ ugyanakkor arra is rámutatott, hogy Statius és Martialis érvényesülését a magánpatrónusi vagy császári kegy mellett saját anyagi helyzetük és társadalmi pozíciójuk is befolyásolták. Idősebb és Ifjabb Seneca, Lucanus és Petronius példának okáért anyagilag függetlenek voltak, így irodalmi érvényesülésükre kevésbé nyomta rá bélyegét a császári hatalom, emiatt megengedhették maguknak a viszonylagos kötetlenséget.

Newlands, Gervais és Dominik ${ }^{50}$ alapján Statius kapcsolatát a hellenisztikus alkalmi költészet összetett hagyományával nyilvánvalóvá teszi, hogy Statius ${ }^{51}$ Neapolisban született, amely

\footnotetext{
${ }^{48}$ RÜHL 2015. 104-105.

${ }^{49}$ Albrecht 2004. 697.

${ }^{50}$ Newlands - Gervais - DominiK 2015. 8., 10-11.

${ }^{51}$ ADAMIK és AlBRECHT szerint az édesapa lovagi rangú személy volt. Ezzel szemben HEGYI felhívta a figyelmet Statiusnak azokra a soraira (Stat. Silv. 5.3.118-120.), amelyek szerint az elszegényedés miatt az apa már elveszthette a lovagi
} 
az itáliai görög kultúra központja volt. S maga is egy hivatásos, görögül verselő költő fiaként látta meg a napvilágot, aki egyben egy magasan képzett tanár volt. A Silvae-re pedig tekinthetünk igényes, egyedi római versek gyüjteményeként, amelyet egy kettős kulturális miliőben alkottak. Ezek a versek ugyanis a hellenisztikus és augustusi költészet kölcsönhatása révén csiszolódtak ki. Statius költői eszközeiben megtalálható volt a kortárs Quintilianus ${ }^{52}$ által is említett ,, alakzatos beszéd”, (Adamik Tamás fordítása). Statius művészete egy kifinomult párbeszédnek is tekinthető saját kora és az irodalmi hagyomány között. A Silvae-ben olvasható villa-költemények ${ }^{54}$ általános jelentőségre tettek szert mint önmagukban is megálló képleírások (ekphraseis). Statius pedig merészen korszerüsítette a Horatius és Vergilius költészetébe beágyazott erkölcsi értékeket azzal, hogy helyeselte a bölcsen felhasznált gazdagságot, példának okáért a fényüző vidéki villa esetében. Statius munkáit egy összefüggő vállalkozásként kell egybeolvasni, amelyben az egyik mű szolgáltat adalékokat a másikról az értelmezés tekintetében, miközben a művek történeti és kulturális kontextusukra egyaránt utalnak.

Vessey ${ }^{55}$ szerint a Silvae legnagyobb része az ünnepi vagy magasztaló szónoklat keretei között, illetve az utóbbihoz társítható müfajok alapján értékelendő. S noha a szónoki stílus ismerhető fel a versek hátterében, a versek nem feltétlenül mutatják a sematizmus jeleit. A témák egyébként változatosak, de többnyire az ünnep, a gyász motívumai, ezen kívül az épületekről és mütárgyakról szóló leírások (ekphraseis) dominálnak. Ráadásul az Erdők versei betekintést nyújtanak a Flavius-korba, azon belül Domitianus korának társadalmi viszonyaira a római elit körében.

Spencer ${ }^{56}$ úgy vélte, hogy a Silvae impresszionista módon teremtett egy irodalmi értelemben vett ,,ligetet”, amely ingatlanokból, pihenő parkokból és a gazdag patronátus miliőjéből tevődött össze. Mindezt a szabadidő (otium) ihlette, amely mellőzte a vidéki birtok gazdasági aspektusait. A versgyűjtemény egyes darabjai tájképeket, tudós szabadidőt hoztak létre és helyeztek egymás mellé. Az individualista hangvételű versek pedig eléggé hivalkodóan festették le ezeket a tájképeket és az intellektuális tartalmú szabadidőt.

rangot. Statius pályáját egyaránt kísérte siker és sikertelenség. A Domitianus által alapított capitoliumi és albai költői versenyek hozták el számára a felemelkedést. S egy újabb költői versenyen, a Kr. u. 94-ben rendezett capitoliumin elszenvedett kudarca után vonult vissza. A kudarc előtt azonban Domitianus császár pártfogását is élvezhette. Nem számított szegény, de ugyanakkor dúsgazdag költőnek sem. Statius (Stat. Silv. 3.1.61-64.) rendelkezett az Albanus hegyének környékén birtokkal (rus) lásd AdAmik 2009. 547.; AlBRECHT 2004. 736-737. és HeGYi 1979. 14-18. Ez a birtok a mai Castel Gandolfo környékén feküdt lásd MARZANo 2007. 10. Véleményem szerint a birtok magában foglalhatott egy villát. Ott, ahol császári pártfogója is magának mondhatott egy vidéki palotát. Feltevésem azon alapul, hogy Horatius sabinumi birtoka is adomány volt Maecenastól, közvetve Augustustól, s a birtok rendelkezett egy villával. Ezt a villát a kutatás a Licenza völgyében, a mai Roccagiovine település közelében feltárt villa maradványaival azonosította. Martialis pedig szintén birtokolt villát Nomentumban (Mart. 12.57.), majd később - némi támogató segítség révén - a hispániai Bilbilis (Mart. 12.31.) közelében.

${ }^{52}$ Quint. Inst. 9.2.65-8. Quintilianus szerint az alakzatos beszédet bizonyos esetekben a gyönyörködtetés érdekében használták, mert újdonságot és változatosságot, azaz írói szellemességet hordozott magában.

${ }^{53}$ Statius költészete visszautalt Kallimakhosz, Ovidius, Horatius, Propertius vagy éppenséggel Vergilius művészetére lásd MYERS 2015. 31., 46-53.

${ }^{54}$ Stat. Silv. 1.3.; 2.2.

${ }^{55}$ Vessey 2001. 926.

${ }^{56}$ SPENCER 2010. 104-105. 
Roman $^{57}$ alapján, amíg a vidéki kivonulás (secessus) látszólag a költői autonómia kulcsmotívumaként funkcionált az Augustus-korban, addig Statius inkább egy hosszabb költői leírást szentelt patrónusai elegáns vidéki villáinak, mintsem a sajátjának. A Flavius-kor költői ${ }^{58}$ azonban nem kevésbé voltak villa-tulajdonosok mint Horatius ${ }^{59}$ vagy Tibullus. ${ }^{60}$ A Flavius-kori költők viszont távol tartották magukat attól, hogy szerzői pozíciójukat feltűnő módon azonosítsák a vidékre történő elvonulással. Egy független erősség (a vidéki villa metaforikus képe) ugyanis nehezen lett volna összeegyeztethető egy egyébként szerény és szolgálatkész kliens-költő hajlékával. Végső soron pedig sem Statius ${ }^{61}$ sem pedig Martialis ${ }^{62}$ nem írták le a paupertas (költői szerénység) alapelvét. Míg Horatius ${ }^{63}$ és az elégia-költők ${ }^{64}$ erkölcsi pozíciójukat az anyagi jóléttel szemben kinyilvánított közönyükre alapozták, addig a Flavius-kor költői ${ }^{65}$ szkeptikusok voltak a magasra emelt paupertas alapelvével és erőteljesen méltatták patrónusaik nagyszerü ingatlanait, továbbá ultra-kifinomult életmódjukat. A Flavius-kori költők ugyanakkor élelmesek voltak a felismerésben is, emiatt briliánsan alkalmazkodtak a változó kultúra áramlataihoz. A költő berke (mint a költői szabadság metaforikus helyszíne) egy nem túl erős irodalmi klisé volt, amelyre senki sem tarthatott igényt sokáig közönyös módon. A villa mint a szerzői önállóság helyszíne pedig - Roman szerint - egész egyszerüen elavult, az elmúlt generáció vezérlő irodalmi trópusa volt. Utóbbi ugyan továbbra is megfelelt a nagy emberek már eleve jelentős presztízsének irodalmi babérokkal való gyarapításához, viszont ugyanez az elv már nem volt alkalmas a társadalmilag alacsonyabb rendű, de elszántan törekvő költők számára, mint Statius és Martialis.

A vidékre történő kivonulás költői motívuma - Roman megállapításai ellenére - azonban a Flavius-korszakban is képviseltette magát. Martialis ${ }^{66}$ epigrammáiban szemléletesen írta le a nagyvárosi Róma kellemetlenségeit, amelyekkel szemben a vidék, illetve nomentumi birtoka kikapcsolódást és nyugalmat kínáltak. Martialis szívesen kereste fel a latiumi Anxur szépnek mondott tengerparti táját is, amelyet villák öveztek és a vidéki időtöltés kellemes baráti társaságban, a múzsák patronálta tevékenységekkel telt el. A költő azonban szembeállította Anxurral kapcsolatos versével ${ }^{67}$ a vidék és a város értékeit. A vidéket a természet közelsége és a kötetlenség jellemezték. A város viszont a kultúra és a civilizáció otthonának számított, amelynek emblematikus intézményei a fórum, a színház és a fürdő voltak. Spencer ${ }^{68}$ felhívta a figyelmet

\footnotetext{
${ }^{57}$ Roman 2015. 457-458.

${ }^{58}$ Vö. Stat. Silv. 3.1.61-64. és Mart. 12.57.

${ }^{59}$ Hor. Ep. 1.16.4-14.

${ }^{60}$ Hor. Ep. 1.4.2. lásd Mart. 2.53.4.

${ }^{63}$ Hor. Od. 2.15., 16., 18.

${ }^{64}$ Vö. Prop. 2.19. és Tib. 1.1.

${ }^{65}$ Vö. Mart. 4.64.; 7.17. és Stat. Silv. 2.2.

${ }^{66}$ Mart. 6.43.; 10.58

${ }^{67}$ Mart. 10.51.

${ }^{68}$ SPENCER 2010. 112.
}

${ }^{61}$ Stat. Silv. 1.4. A paupertashoz köthető tradíció emlékei azonban továbbra is tartották magukat a költészetben. Statius fentebb hivatkozott versének vége felé hozzáértő módon idézte fel a költői paupertast, jóllehet egy olyan kontextusban, amely végtére is korlátozta az érvényességét lásd RomAN 2014. 292.

${ }^{62}$ Martialis hirdette epigrammáiban az egyszerű életet és látszólag szívesen elutasította a nagy vagyont, beérve akár egy szerényebb villával lásd Mart. 4.64.; 10.47. Időnként azonban ő is gúnyolódott a kevéssel beérés eszményén 
Statius ${ }^{69}$ egyik villa-versének arra a részére is, amely alapján a tulajdonos, Pollius Felix surrentumi villája Campaniában egyfajta menedéket nyújtott a közélet és a lelki viharok elől. A költő szintén lelki nyugalmat kívánt a nyilvánosságtól már visszavonult címzett számára, amelyet a táj, a villa, továbbá a költészet és a filozófia művelése együttesen hivatottak biztosítani. A surrentumi parton álló elegáns épület rokonítható Nomentum költői leírásával, igaz, ebben a kontextusban a gazdag patrónus és nem a költő menedéke került megörökítésre.

Martialis és Statius költészete ugyanakkor adalékokat szolgáltat a kliens-költő igényelt magánszférájával kapcsolatban is. Erre utal Martialisnak ${ }^{70}$ a nomentumi birtokával kapcsolatos másik verse az Epigrammák 6. könyvéből, amely Kr. u. 90 körül látott napvilágot, tehát Domitianus uralma alatt, a „,kliensi” szerep gyakorlásának idején. Az Epigrammák 12. könyvének 18. darabjában ${ }^{71}$ Martialis pedig megható sorokban örökítette meg kedélyes és szeretett bilbilisi birtokát. Ezt az ingatlant egyfajta révként jelenítette meg a szülőföldjére (Kr. u. 98-ban) visszatért és letelepedett költő. A 12. könyv Kr. u. 101-102 körül állhatott össze. Martialis ekkor már maga mögött hagyta a fővárost s valószínűsíthetően a kliens-költő szerepét is. Már nem kellett attól tartania, hogy bilbilisi villájának költői képe túlhangsúlyozta volna a költői függetlenséget a patrónusokkal szemben. A birtok képe a békés öregkor lehetőségét vetítette előre, egy olyan otthonét, ahol tényleg félre lehetett rakni a hivatalos és városi élet jelképét: a tógát. Statius ${ }^{72}$ pedig a capitoliumi költői verseny alatt elszenvedett veresége után megírta feleségének azt a versét, amelyben a szülőföld, Neapolis iránti vágyát fejezte ki. Statius számára Neapolis a szükséges visszavonulás és az óhajtott intimszféra terepeként lépett elö, amely a nyugalmas, ugyanakkor élményekkel és szépségekkel teli öregkor ígéretével kecsegtetett a költő és felesége számára.

Roman $^{73}$ további gondolatait alapul véve, az önreprezentáció Augustus-kori modelljei tehát részlegesen, de mégis meghatározó jelleggel maradtak fontosak a Flavius-korabeli irodalmárok számára. Emiatt érthető, miért fordultak Catullushoz ${ }^{74}$ is, akinek játékos hangneme alkalmas volt arra, hogy megcsipkedje a költői komolyságot. Ráadásul Catullus erkölcsi állásfoglalása épp az ellentéte volt az ünnepélyességnek vagy az emelkedettségnek. Statius és Martialis pedig kimutatták találékony hajlamukat az irodalmi hagyomány különböző elemeinek az összekombinálásához, így mindketten az augustusi elődökkel vagy velük szemben dolgoztak, példának okáért szelektíven asszimilálták Catullust. Az egymástól eltérő álláspontokra helyezkedve, Martialis és Statius ugyan létrehozták a kliens-költőt, aki ügyelt arra, hogy a feljebbvalóival szemben nyílt hódolóként mutassa be magát, azonban más pillanatokban megcsillogtatta szabadosságát (libertas) és merészségét (licentia). A kliens-költő - függve a kontextustól, helyzettől és címzettől lehetett hízelgő, cinikus, ravasz, tartózkodó és szatirikusan maró. Mégis, a rugalmasság volt a kliens-költő alapvető erőssége. Statius viszont nyíltan idealizálta a római uralkodó réteg képességét az irányítás, átalakítás és végső soron a finomítást illetően a természet felett az ügyes leleményesség és a kimeríthetetleneknek tűnő erőforrások révén.

\footnotetext{
${ }^{69}$ Stat. Silv. 2.2.121-146.

${ }^{70}$ Mart. 6.43.

${ }^{71}$ Mart. 12.18.

${ }^{72}$ Stat. Silv. 3.5.12-13., 31-33., 76., 85-88.

${ }^{73}$ Roman 2015. 457-458.

${ }^{74}$ Mart. 1.praef.; 1.7.; 1.109.; 2.86. Vö. még Stat. Achill. és Catul. 64. lásd Ripoll 2015. 440.
} 


\section{Manilius Vopiscus Tiburi ViLláJa}

Az alábbiakban egy olyan villa és tulajdonosa kerülnek bemutatásra, amelyek irodalmi képei egymással kölcsönös összefüggésben álltak Statius költészetében, azaz tulajdonos és villája egymást feltételezték a reprezentáció aktusában.

Nauta $^{75}$ szerint a vers címzettje, Vopiscus nem egy könnyen meghatározható személy. Jó eséllyel azonban egy igen sikeres szenátori család tagja és egyben Statius patrónusa volt, aki villájában az irodalomnak szentelte magát. A versben ${ }^{76}$ ugyanis egy Tiburban (Latium) ingatlannal rendelkező költőként jelent meg. Newlands ${ }^{77}$ is patrónusként tekintett Vopiscusra és hangsúlyozta, hogy Vopiscus inkább barátként, vendéglátóként jelent meg a versben, viszont kettejük egymáshoz füződő viszonya nem lett megnyugtatóan tisztázva. Feltehető, ahogy az ábrázolt villa, úgy Vopiscusnak a költeményben lefestett személye is valamilyen szinten költői kép: egyfajta szemléltető eszköz az irodalompártolás érdekében.

Mitchell $^{78}$ szerint a kép a természetesség és az átlátszóság illúzióját nyújtja, azonban az önhatalmúlag végzett reprezentáció és a misztifikált ideológia elpalástolására is szolgál. A grafikus kép (pl. festmények, szobrok, tervrajzok) a szövegkontextus müködése révén mentális (leírások), verbális (metaforák) és észlelési (érzéki, észlelhető formák) képpé alakulhat át. A mentális kép az összes érzékszervet képes mozgásba hozni. A leírás során feltételezhető egy további elme, amely végrehajtja a dekódolás folyamatát, s ebben az elmében megjelenik a szövegben leírt kép. Spencer ${ }^{79}$ alapján Statius ${ }^{80}$ villa-versének legelején előtérbe helyezte a hőérzetet (a villa hüvösségének kiemelésével) és a hallást (Vopiscus ékesszólására utalva), amikor bevonta az olvasókat a versben lefestett tiburi villa tájképébe. Ezt követően gyorsan kapcsolatot teremtett az érzékelésekre utaló kifejezések, élvezet, gyönyör, emlékezet és mimésis között. Utóbbi kettő egyaránt utalt arra, hogy itt egy valóságban is fellelhető, igényes villa müvészileg újraalkotott képe, s egy, az elit által ismert életforma felidézésről van szó. Statius ${ }^{81}$ az olvasói tekintetnek is irányt szabott ebben a villa-tájképben. Az elit által megszokott választékos, ünnepélyes hangulatú költői nyelv

\footnotetext{
${ }^{75}$ NAUTA 2002. 226.

${ }^{76}$ Stat. Silv. 1.3.22-23. ,... murmura, ceu placidi veritus turbare Vopisci/Pieriosque dies et habentes carmina somnos. ” (,,... drága Vopiscusnak mintegy kímélni akarja/múzsai napjait és költészettel tele álmát.” Ford. Muraközy Gyula)

${ }^{77}$ Newlands 2002. 127-128. Az új típusú tájleírás kapcsán érdemes felidézni a Nero-korabeli Calpurnius Siculus eclogáit is. Ezek a versek merészen cserélgették fel Vergilius témáit és fontos közvetítő szerepre tettek szert Vergilius és Statius bukolikus költészete között lásd Calp. Ecl. 4.; 7. Ezekben a versekben a vidék reprezentációja már lehetett bájtalan, a paraszti ideál színhelye pedig nem kapcsolódott össze megfelelő pártfogókkal, akik a feltörekvő költőket segítették volna. Calpurnius Siculus ,,pásztor-költői” a vidéket bizonyos szempontból durvának látták és a városba vágytak, amelyet a művészetek és a tanulmányok központjának tartottak, s amit a patronátus egyetlen forrásának tekintettek lásd NEWLANDS 2002. 143., 150.
}

${ }^{78}$ Mitchell 2005. 118-129.

${ }^{79}$ SPENCER 2010. 106.

${ }^{80}$ Stat. Silv. 1.3.1-2.

${ }^{81}$ Stat. Silv. 1.3.24-26., 34-46., 58-60. , litus utrumque domi, nec te mitissimus amnis/dividit: alternas servant praetoria ripas,/non externa sibi fluviorum obstare queruntur.” „, Quid primum mediumve canam, quo fine qiuescam?/auratasne trabes an Mauros undique postes/an picturata lucentia marmora vena/mirer, an emissas per cuncta cubilia nymphas?/huc oculis, huc mente trahor. venerabile dicam/lucorum senium? te, quae vada fluminis infra/cernis, an ad silvas quae respicis, aula, tacentis,/qua tibi tota quies offensaque turbine nullo/nox silet et nigros imitantia murmura somnos?/an quae 
és a költő által felkínált emlékezettechnikai gyakorlat ${ }^{82}$ pedig még érzékletesebbé tették a villáról szóló leírást a művelt olvasók számára. Spencer arra is rámutatott, hogy a versben a tájképre irányított olvasói tekintet a látvány hatásos pontjainak a megkonstruálását szolgálta. E pontok egyaránt utaltak a villa lehetséges, fényűző részeire és a szellem művelésének lehetőségére a villán belül. A versben a villa kontextusát a városi környezet elitista értelemben vett értékei hozták létre. A vers bevezetőjében Statius ${ }^{83}$ epikus, mitológiával átitatott képeket szerepeltetett és az elit villa-kultúrájában fellelhető ismerős motívumok kombinációi szolgáltak a költő távlati rajzának alapelemeiként.

Az emlékezettechnika miatt érdemes felidézni a Statiusszal kortárs Quintilianus ${ }^{84}$ gondolatait az emlékezettechnikai módszer kapcsán. A gyakorlat szerint érdemes kiválasztani vagy elképzelni egy több helyiségből álló házat. Az emlékezés során nemcsak egyes, sajátos helyiségek újbóli felidézése történik, hanem az emlékben újabb emlékeket helyez el a gyakorlat végzője. A mondanivalót az egyén fogalomba tömöríti és az egyes helyiségekben hagyja. Mikor pedig újrakezdi az emlékezést a személy, a helyiségekkel együtt a fogalmakat is felleli, amelyeket kibontva egymás mellé füz fel. Statius ${ }^{85}$ saját bevallása szerint emlékezetből írta le Vopiscus villáját és a villához kapcsolódó többletjelentésű gondolatokat és utalásokat helyezett el a versben, amelyeket a villa ${ }^{86}$

graminea suscepta crepidine fumant/balnea et impositum ripis algentibus ignem,/quaque vaporiferis iunctus fornacibus amnis/ridet anhelantes vicino flumine nymphas?” „Quid nunc iungentia mirer/aut quid partitis distantia tecta trichoris?/quid te, quae mediis servata penatibus arbor/tecta per et postes liquidas emergis in auras, /quo non sub domino saevas passura bipennes?” (,,Mindkét part a tied, ház, s nem szel e legszelidebb ár/kétfele, mindkét partot e nagyszerü épület őrzi, s nem panaszolja, hogy öt idegen víz árja zavarja.” „Hol kezdjem, folytassam a dalt, s mit mondjak utólszor?/Mit bámuljak előbb? Az aranyló mennyezetet vagy/mór ajtók tömegét, ragyogó márványerezetnek/színét, s azt, hogy a víz eljut valamennyi szobába?/Erre szemem, lelkem húz arra. Daloljam a tisztes ös fáknak ligetét? Vagy a termeket: azt, mely a vízen/túlra tekint, vagy mely szemléli a hallgatag erdöt,/hol nem moccan a csend, s orkánt sose látva nyugodtan/hallgat az éj, hol a fák feketén szunnyadva pihennek/vagy, hogy a fürdök mint gözölnek gyeppel övezve,/s hogy lángtól melegülnek a hüs partok, s a folyónak/istene gözt lehelö kályhákba befogva a szomszéd/vízárban lihegö nimfákat hogy kikacagja?" „S bámuljam-e most a középsö/épületet vagy a két szárnyrészt hármas termével?/Vagy téged, fa, amely, megtartva, a ház közepén állsz,/s nyúlsz a tetö, a gerenda közén fel a híg levegöbe..." Ford. Muraközy Gyula)

${ }^{82}$ Stat. Silv. 1.3.13-17. „O longum memoranda dies! quae mente reporto/gaudia, quam lassos per tot miracula visus!/ingenium quam mite solo, quae forma beatis/ante manus artemque locis! non largius usquam/indulsit natura sibi. ” (,,Ó, örök emlékü ez a nap! Lelkem mily örömmel/telt el, mennyi csodán bágyadt káprázva e két szem!/Mily békés ez a hely! S emberkéz müve elött is/mily szép volt ez a boldog táj! Nem hagyta magát így/máshol a Természet pazarolni! ..." Ford. Muraközy Gyula)

${ }^{83}$ Stat. Silv. 1.3.5-12.

${ }^{84}$ Quint. Inst. 11.2.18-21.

${ }^{85}$ Stat. Silv. 1.3.13-14.

${ }^{86}$ Stat. Silv. 1.3.1-12. „Cernere facundi Tibur glaciale Vopisci/si quis et inserto geminos penates,/aut potuit sociae commercia noscere ripae/certantisque sibi dominum defendere villas, /illum nec calido latravit sirius astro/nec gravis aspexit Nemeae fondentis alumnus:/talis hiemis tectis, frangunt sic improba solem/figora, Pisaeumque domus non aestuat annum./Ipsa manu tenera tecum scripsisse Voluptas...” „,unc Venus Idaliis unxit fastigia sucis/permulsitque comis blandumque reliquit honorem/sedibus et volucres vetuit discedere natos.” (, Azt ki elött megnyilt laka hüs Tiburban az ékes/ajku Vopiscusnak - ház, mit ketté Anio oszt-,/s látta, mily elragadó módon függ össze a két part,/és villáit, amelyek uruk versenyt hivogatják:/Sirius izzó csillaga azt nem ugatta meg, ádáz/szemmel rá ligetes Nemeának szörnye se nézett;/oly hüs itt belül, oly tartós hideg üzi a napfényt,/Pisának nyara sem gyözhet melegével e házon./Ezt a Gyönyör tervezte veled, maga gyenge kezével...” „Majd Venus Idalium nedvével kente be ormát,/s rálebbentve haját, otthagyta a házon igézö/báját, s szárnyas sarjait ott tartotta parancsa.” Ford. Muraközy Gyula) 
vagy bizonyos helyiségének, ${ }^{87}$ a ház körüli kertnek, ${ }^{88}$ továbbá a környező tájnak ${ }^{89}$ a kiemeléseivel aktivált.

Newlands ${ }^{90}$ elemzésében Statiust olyan költőként kezelte, aki nyíltan kesztyüt dobott a fényüzés kritikusai, legfőképpen Horatius ${ }^{11}$ elé. Horatius ugyanis nem egy minden luxus-igényt kielégítő életstílussal kötötte egybe a villabeli életmódot. Másfelöl a magánház Horatius ${ }^{92}$ költészetében gyakran a természet elferdítéseként jelent meg, s szimbóluma volt a fizikai és erkölcsi kicsapongásnak. Horatius $^{93}$ azonban bizonyos megnyilatkozásaiban a kellemességeket lehetővé tevő technológiát és pénzt szükségteleneknek tartotta, az értük való sóvárgást pedig irracionálisnak. A költő ${ }^{94}$ saját birtokát is szerénynek kívánta beállítani. Statius ezzel szemben szemérmetlenül propagálta lelkesedését Vopiscus birtokának fényüzése iránt. Vopiscus Tiburjában a víz és a fák egy gazdag ingatlan részeiként funkcionáltak. Az épület mint újfajta locus amoenus árnyékának köszönhető hűvösségét itt a ház építészeti kialakítása teremtette meg. Maga a ház a legdrágább anyagokból épült5

\footnotetext{
${ }^{87}$ Stat. Silv. 1.3.57-63. „, Quid nunc iungentia mirer/aut quid partitis distantia tecta trichoris?/quid te, quae mediis servata penatibus arbor/tecta per et postes liquidas emergis in auras, /quo non sub domino saevas passura bipennes?/et nunc ignaro forsan vel lubrica Nais /vel non abruptos tibi demet Hamadryas annos. " (,S bámuljam-e most a középsö/ épületet vagy a két szárnyrészt hármas termével?/Vagy téged, fa, amely, megtartva, a ház közepén állsz,/s nyúlsz a tetö, a gerenda közén fel a híg levegöbe;/mely más gazda alatt kímélne a fejsze vad éle?/Ám most félbe - urad tudtán kívül sose bántott/éveid egy iszamos nais vagy nimfa szakasztja." Ford. Muraközy Gyula)

${ }^{88}$ Stat. Silv. 1.3.81-94. „Quid bifera Alcinoi laudem pomaria vosque,/qui numquam vacui proditis in aethera, rami?/cedant/Telegoni, cedant Laurentia Turni/iugera Lucrinaeque domus litusque cruenti/Antiphatae; cedant vitreae iuga perfida Circes/Dulichiis ululata lupis arcesque superbae /Anxyris et sedes Phrygio quas mitis alumno/debet anus; cedant, quae te iam solibus artis /avia nimbosa revocabunt litora bruma./Scilicet hic illi meditantur pondera mores; haec premitur fecunda quies virtusque serena/fronte gravis sanusque nitor luxuque carentes /deliciae, quas ipse suis digressus Athenis/mallet deserto senior Gargettius horto;” (, Zengjelek, Alcinous kétszer termő csoda fái?/Ágak, amik termés nélkül sose nyúltok a légbe?/Telegonus s Turnus Laurentuma fel sose érhet/ezzel, s Lucrinus tava és bösz Antiphatesnek/berke, s a szép Circe büvös hegye sem, hol Ulixes/farkasnépe üvöltött, sem hegyi vára a büszke/Anxurnak, sem a táj, mit sirul nyert el a jámbor/dajka a fríg höstöl, sem a parti vidék, ami megvéd/téged majd a borús téltöl, ha a nap köre szükül./Mert hisz a nagy kérdéseken itt töprenkedik elméd,/itt termékeny a csend, s vidul arca a súlyos erénynek;/itt az öröm józan, s fényüzés nélküli jólét/csillog./Még az öreg gargettusi bölcs is örömmel/átköltözne, Athént s kertjét otthagyva, tehozzád.” Ford. Muraközy Gyula)

${ }^{89}$ Stat. Silv. 1.3.20-33. ,ipse Anien (miranda fides) infraque superque/saxeus hic tumidam rabiem spumosaque ponit/ murmura, ceu placidi veritus turbare Vopisci/Pieriosque dies et habentes carmina somnos./litus utrumque domi, nec te mitissimus amnis/dividit: alternas servant praetoria ripas,/non externa sibi fluviorum obstare queruntur./Sestiacos nunc Fama sinus pelagusque natatum/iactet et audaci victos delphinas ephebo: hic aeterna quies, nullis hic iura procellis,/ numquam fervor aquis. datur hic transmittere visus/et voces et paene manus.sic Chalcida fluctus lexpellunt.fluvii, sic dissociata profundo /Bruttia Sicanium circumspicit ora Pelorum." (,, Sziklákon zuhog át Anio fentebb meg alantabb,/ ám - csoda hódolat - itt nem zúg dühösen habos árja;/drága Vopiscusnak mintegy kímélni akarja/múzsai napjait és költészettel tele álmát./Mindkét part a tied, ház, s nem szel e legszelidebb ár/kétfele, mindkét partot e nagyszerü épület őrzi,/ $s$ nem panaszolja, hogy öt idegen víz árja zavarja./Hát csak hordja a hír ama sestusi öblöt, az átszelt/tengert s delfineket megszégyenitö merszét!/Itt örökös csend ül, mennydörgés itt sose zendül,/hab sose forrong. Hang, a tekintet könnyeden ér át/s szinte a kéz is. Eként különiti a chalcisi földet/el folyamár, s így nézi a tenger mély szorosán át/ bruttiusok partszéle Szicilia-földi Pelorust.” Ford. Muraközy Gyula)

${ }^{90}$ Newlands 2002. 130-133.

${ }^{91}$ Vö. Hor. Od. 3.1.33-37. és Hor. Sat. 2.6.

${ }^{92}$ Hor $O d .2 .15 . ; 2.18$.

${ }^{93}$ Hor. Od. 2.16.9-12.

${ }^{94}$ Hor. Od. 2.18.1-14.

${ }^{95}$ Stat. Silv. 1.3.35-36. „, auratasne trabes an Mauros undique postes/an picturata lucentia marmora vena...” (,, Az aranyló mennyezetet vagy/mór ajtók tömegét, ragyogó márványerezetnek/szinét...” Ford. Muraközy Gyula)
} 
és rendelkezett a legújabb technológia ${ }^{96}$ nyújtotta kényelemmel. Vopiscus villája látszólag igen távol esett az epikureizmus hirdette ,józan szerénység” ideáljától a maga nagyszerű, választékos kialakításával, gazdag díszítettségével és berendezésével. Statius ${ }^{97}$ ennek ellenére hangsúlyozta, hogy Epikuros jobban kedvelte volna Vopicus ingatlanát az athéni kertjeinél. E kijelentés első olvasatra talán túlzásnak tűnik. Az extravagáns ház ugyanis maga után vonta a környező természet extravagáns kialakítását is. Vopiscus háza ennek ellenére harmóniában állt a természettel, nem pedig megerőszakolta azt. A római kerteket ugyanis olyan építészeti elemeknek gondolták el, amelyek a ház kiterjedései voltak. Ezek aztán adaptálódtak a ház beosztásához. Ahogy a ház, úgy a természet is gazdagnak tűnt fel a versben. A pásztori, földmüves ideák a tájépítészet és a kertkialakítás ${ }^{98}$ során új fogódzókkal kapcsolódtak az új technikai fogásokhoz és emberi igényekhez. Összességükben viszont így váltak az emberi beavatkozással megteremtett tájképi művészet szépségének a hirdetőivé. A technika és a természet erőforrásai egyaránt képviseltették magukat a fényűző villában: a szabályozott és csövekbe terelt víz, a fák és az árnyék a villa díszítőelemeiként szolgáltak és tulajdonképpen a díszítő funkciónak lettek alárendelve. A költészet és erény ideális helyszíne így a ,szakrális-pásztori” tájról áttevődött a fényüző házra, továbbá annak gondosan megtervezett és kialakított környezetére. A táj egyszerű elemei (pl. árnyékosság, fa, patak) pedig feloldódtak ebben a felfogásban, ezért mostantól kezdve a villa abszolút uralta a tájat.

Newlands ${ }^{99}$ tehát Statius felfogását Horatius költészetével ütköztette. Horatius az Episztolák 1. könyvének 10. versében a vidéket kérdések formájában magasztalta fel a városi fényüzéssel szemben. Provokatív módon tette fel a kérdést, ${ }^{100}$ vajon a márványkövekből kirakott mozaikpadló jobban fénylett vagy illatozott-e a pázsitnál? Vopiscus villájában szintén volt egy különleges mozaikpadló,

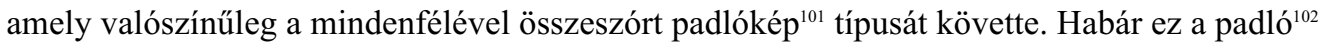
a természeten való felülemelkedést reprezentálta, abban mégis igazolást nyert, hogy az így „,feldiszitett talaj örömét lelte saját változatos müvészetében”. A természet hálás reakciója azt sugalmazta, hogy Vopiscust olyan jótevőnek és civilizátornak lehetett tekinteni, akinek a fényűzése a természetet és a vidéki tájat gyarapította. S valóban: a mennyezetről aláhulló fényzuhatag és a padló élénk, az üvegablakokon visszatükröződő képe egy másik, a természet és művészet közti kölcsönösség harmonikus képét alkotta meg, amely magában a házban ${ }^{103}$ jött létre.

${ }^{96}$ Stat. Silv. 1.3.67. „Marcia, et audaci transcurris flumina plumbo?” (,,... bátran Marcia, fent iramodsz ólomvezetékben...” Ford. Muraközy Gyula)

${ }^{97}$ Stat. Silv. 1.3.93-94.

${ }^{98}$ Az Oplontisban feltárt egyik villa ismertetése kapcsán érdemes megjegyezni, hogy a díszkertek létesítése és karbantartása külön mesterségnek számított a rómaiaknál. A geometrikus alakzatokat magában foglaló kert, a nyírott bokrokkal, fákkal és a közéjük helyezett lugasokkal élő müalkotásnak számítottak (opus topiarium). Az épület és a növényzet így architektonikus egységet alkottak lásd CARO 2005. 386.

${ }^{99}$ Newlands 2002. 133-136.

${ }^{100}$ Hor. Ep. 1.10.19. ,, deterius Libycis olet aut nitet herba lapillis?” (,Illatosabb, ragyogóbb Libya mozaikja a fünél? ” Ford. Bede Anna)

${ }^{101}$ Plin. Nat. 36.184.

${ }^{102}$ Stat. Silv. 1.3.55-56.

${ }^{103}$ Stat. Silv. 1.3.52-57. „,dum vagor aspectu visusque per omnia duco,/calcabam necopinus opes. nam splendor ab alto/defluus et nitidum referentes aera testae/monstravere solum, varias ubi picta per artes/gaudet humus superatque novis asarota fuguris. " (, Tévedezö szememet míg hordozom erre meg arra,/lábam kincsre tipor véletlen. Mert a magasból/ rázuhogó s üvegablakokon megsokszorozódó/fényben látszik a padló, és ezer új figurával/vígan fénylik a kö, szebb minden más mozaiknál,/s visszariaszt lépnem." Ford. Muraközy Gyula) 
Idézett episztolája másik helyén Horatius ${ }^{104}$ megkérdőjelezte a csövekben folyó víz kiválóságát a nyílt folyóvízzel szemben. Horatius itt - a természet-párti indoklás érdekében - leszólta a városlakónak a vízvezetékrendszerbe vetett bizalmát, amely viszont a római technológia alapvető elemének számított a civilizáció létrehozásában. Vopiscus bővében volt a víznek saját birtokán, sőt egy tökéletes villában általában kellő vízbőségnek ${ }^{105}$ kellett lennie. Vopiscus villájában ${ }^{106}$ minden hálószobába bevezették a vizet és a partra kitelepedő lakomázók egyszerre gyönyörködhettek a fürdőépületekben vagy az ingatlan területén egymást keresztező természetes (Anio) és mesterséges (Aqua Marcia) folyóvizekben, mely utóbbi vizet szállított csővezetékében Rómába. A természeti és építészeti szépségek tehát elválaszthatatlanul egybeforrtak, amelyre már Propertius ${ }^{107}$ is utalt korábban. Horatius fentebb idézett episztolájában a víz erőszakos megszűrése, hogy majd csövekből fakadjon elő, természetellenes beszabályozás volt. Vopiscus birtokán ${ }^{108}$ viszont a víznek a csőben történő surranása békés cselekedetnek számított, így nem volt szüksége erőlködésre, hogy kitörjön kötelékeiből. A csőben folyó víz ezért inkább az anyagi előrehaladást reprezentálta semmint az erkölcsi züllést. Sőt, a vízvezeték megléte rámutatott az ingatlan önellátására, amely rendelkezett mindazon kellemességekkel, amik megtalálhatóak voltak a fővárosban. Statius tehát félretette a természetet kizsákmányoló technológia negatív képét, mivel újra bebizonyosodni látszott, hogy a természet ,„örült” a beavatkozásnak. Az Anio és mellékfolyóinak, a Tiburnusnak és az Albulának a megszemélyesített istenalakjai ${ }^{109}$ is eljöttek éjszaka, hogy élvezzék a tiszta vizeket. A fürdőket, amelyek az Anio vizét használták, szintén a folyópartra építették. Ebben az esetben sem volt szó arról, hogy a folyót úgy kezelték volna, mint egy szolgát, ami ellenállt és erőszakosnak bizonyult a betörése miatt. Ellenkezőleg, az Anio a legnyájasabb vízfolyásnak számított, még akkor is, ha a fürdő jármába terelték. Végül Horatius ${ }^{110}$ a 10 . episztolában

${ }^{104}$ Hor. Ep. 1.10.20-21. ,purior in vicis aqua tendit rumpere plumbum,/quam quae per pronum trepidat cum murmure rivum?” (,,Jobb-e a víz, mely az ólomcsö vezetékein átfolyt,/mint amelyik lejtös partok közt, játszva csilingel??” Ford. Bede Anna)

${ }^{105}$ Vö. Cato Agr. 1.6.; Col. 1.5.1-2. és Var. r. r. 1.13.3.

${ }^{106}$ Stat. Silv. 1.3.37., 43-46., 64-69. ,....mirer, an emissas per cuncta cubilia nymphas?” „an quae graminea suscepta crepidine fumant/balnea et impositum ripis algentibus ignem,/quaque vaporiferis iunctus fornacibus amnis/ridet anhelantes vicino flumine nymphas?” ,"quid referam alternas gemino super aggere mensas/albentesque lacus altosque in gurgite fontes?/teque, per obliquum penitus quae laberis amnem,/Marcia, et audaci transcurris flumina plumbo?/ an solum Ioniis sub fluctibus Elidis amnem/dulcis ad Aetnaeos deducat semita portus?” (,... s azt, hogy a viz eljut valamennyi szobába? ” „... vagy, hogy a fürdök mint gözölnek gyeppel övezve,/s hogy lángtól melegülnek a hüs partok, s a folyónak/istene gözt lehelö kályhákba befogva a szomszéd/vizárban lihegö nimfákat hogy kikacagja? ”, ,Szóljak a két parton felváltva adott lakomákról,/viz mélyén fakadó forrásról, tiszta tavakról,/vagy rólad, ki a gyors Anión itt vágva keresztül/bátran, Marcia fent iramodsz ólomvezetékben?/Tán csak az elisi víz fog az Aetna alatti öbölbel futni ión hab alatt, vegyületlen tartva meg árját?” Ford. Muraközy Gyula)

${ }^{107}$ Prop. 3.22.23-24.

${ }^{108}$ Stat. Silv. 1.3.66-67.

${ }^{109}$ Stat. Silv. 1.3.70-75. , ,illic ipse antris Anien et fonte relicto,/nocte sub arcana glaucos exutus amictus/huc illuc fragili prosternit pectora musco,/aut ingens in stagna cadit vitreasque natatu/plaudit aquas. illa recubat Tiburnus in umbra,/ illic sulpureos cupit Albula mergere crines;...” (,Forrását, üregét Anio odahagyva kibújik/zöld köpenyéböl, hogyha leszáll a titokzatos éjjel,/s testét itt vagy amott elnyújtja szelíd mohaágyon;/majd belecsobban a vizbe hatalmasan, és ahogy úszik,/ver kristály habot. Itt pihen el Tiburnus az árnyban,/s Albula itt vágyik lemeriteni kénszinü fürtjét." Ford. Muraközy Gyula)

${ }^{110}$ Hor. Ep. 1.10.23. , laudaturque domus, longos quae prospicit agros: ” (,„áldva az ablakokat, miken át a mezökre kiláttok? ” Ford. Bede Anna) 
azt is kifogásolta, hogy a villa megkövetelte a körkilátást. A jó kilátás ${ }^{111}$ fontos jellegzetessége volt ugyanis a római villának, s ezzel a kedvező tulajdonsággal Vopiscus villája ${ }^{112}$ természetszerüleg rendelkezett. Ebben az esetben a látkép nem csupán a vizuális gyönyörrel volt összefüggésben, hanem a természet feletti ellenőrzéssel is. Ez egy olyan felügyelet volt, amelyet Horatius kigúnyolt mint az élvezet helytelen formáját. Egyéb irodalmi forrás ${ }^{113}$ viszont tanúsítja, hogy a birtok urának rálátása volt villájából a környező tájra. A látvány ellenőrzése ugyanakkor maga után vonta a hangok ${ }^{114}$ feletti uralmat is. A természet hangjait úgy nyomták el, hogy Vopiscus békésen álmodhatott, olyan emberként, aki mentes volt a mentális és erkölcsi nyugtalanságtól. A látvány és a hang ellenőrzése így metaforikus módon utalt a költő belső kontrolljára. Vopiscus a fentiek segítségével irányította tulajdonát és rendezte el saját tájképét egy kulturális motívumokkal telített és természetesnek ható müvi közegben. Vopiscus tehát fényüző módon élt vidéken egy olyan luxus-villában, amelyet Horatius ${ }^{115}$ bizonyos szinten elutasított. Mindenesetre Statius versében az építészeti és erkölcsi morál szoros kapcsolatba került egymással. Vopiscus úgy tűnik, hogy két világ legjavát birtokolta, azaz rendelkezett a természet harmóniájával szemben Horatiusszal, ${ }^{116}$ aki ugyan szintén erre vágyott, de közben a városban is élvezte a városi kényelmet és komfortot.

Horatiusnál ${ }^{117}$ azonban rábukkanhatunk egy olyan episztolára is, amelyben a falu és a város ellentétét mintegy semmissé tette azzal, hogy a megelégedettséget nem egy bizonyos helyszíntől tette függővé. Ezzel a megjegyzésével pedig megelőlegezte Seneca ${ }^{118}$ megállapítását is.

Borzsák ${ }^{119}$ szerint Horatius sabinumi birtoka a természetességet, függetlenséget és a királyi életérzést szimbolizálta. A versben a falusi élet a helyes és természetes életforma megjelenítője, amellyel szemben a város csupán utánzat. Ha pedig a házat élő növényekkel, mint például ültetett fákkal díszítették fel, akkor éppenséggel a vidék elsőbbségét hirdették a várossal szemben.

${ }^{111}$ Plin. Ep. 2.17.5-6.; 5.6.27.

${ }^{112}$ Stat. Silv. 1.3.39-42. ,... te, quae vada fluminis infra/cernis, an ad silvas quae respicis, aula, tacentis, /qua tibi tota quies offensaque turbine nullo/nox silet et nigros imitantia murmura somnos?" (,,... Vagy a termeket: azt, mely a vizen/ túlra tekint, vagy mely szemléli a hallgatag erdöt,/hol nem moccan a csend, s orkánt sose látva nyugodtan/hallgat az éj, hol a fák feketén szunnyadva pihennek; " Ford. Muraközy Gyula)

${ }^{113}$ Seneca felidézte, hogy tekintélyes római politikusok és hadvezérek, mint például Marius, Pompeius vagy Caesar villáikat a hegytetőre építették. Erődökhöz (castra) való hasonlításuk megengedi azt a következtetést, hogy ezek az ingatlanok képesek voltak kifejezni tulajdonosaik tekintélyét, éppen ezért jól kiépített, a tájat uraló létesítmények lehettek lásd Sen. Ep. 51.11.

${ }^{114}$ Ifjabb Plinius megemlítette, hogy laurentumi villája hálószobájában az építészeti kialakításnak köszönhetően tökéletes csend uralkodott, ugyanis e helyiség és a kert fala között folyosó húzódott, amely elnyelte a hangokat lásd Plin. Ep. 2.17.22.

${ }^{115}$ Hor $O d$. 2.18. Horatius kijelentette, hogy az ő ingatlanát nem ékesítették drága burkolóanyagok. Ezt azzal indokolta, hogy a bölcs nem harácsol hiába, hanem megelégszik a szerényebbel. Feltehető, hogy Horatius saját villáját is költői képként írta le lásd NEWLANDS 2002. 130-131.

${ }^{116}$ Hor. Ep. 1.8.12.; 1.14.6-8. A vidéket oly nagyra becsülő Horatius is alkalomadtán szívesebben tartózkodott a városban, ha például egy hölgyet kellett vigasztalnia bánatában. Saját bevallása szerint időnként Tiburban is Rómába vágyott. Amennyiben pedig a költő intézőjéhez íródott episztola valójában saját magának szól, akkor szemléletes szöveghelyre utalnak a következő sorok lásd Hor. Ep. 1.14.14-15.

${ }^{117}$ Hor. Ep. 1.14.

${ }^{118}$ Sen. Ep. 55.1-8. Seneca szerint a vidéki tartózkodással az ember nem maradhatott távol a világ zajától. A lakóhely ugyanis nem garantálta a nyugalmat, hisz az egyedül a lélektől függött. A bölcs embernek a szabadidejét hasznos tanulmányokkal és helyes életvitellel kellett kitöltenie, nem pedig tunya kényelemmel.

${ }^{119}$ BorzsÁk 1969. 78-81. 
Newlands ${ }^{120}$ alapján azonban Statius felfogásában egy olyan stratégiát vélhetünk felfedezni, amely szerint a kényelem minél nagyobb teret kellett, hogy nyerjen a természetben, azaz a vidéki környezetben. Statius e felfogásával pedig a természet urbanizációját igazolta versében, továbbá összekapcsolta a jól kialakított tájképet a tulajdonos, Vopiscus társadalmi és erkölcsi értékével.

Statius $^{121}$ provokatív és összegző megállapításával - Newlands ${ }^{122}$ alapján - a jólét újfajta értéke mellett érvelt, amely közelebb vitt magához az erényhez. Amikor Statius ${ }^{123}$ áldást kért Vopiscus „, boldog szellemére”, olyan metaforát használt, amely kihangsúlyozta a kapcsolatot az anyagi és erkölcsi jólét között. A költő kölcsönösen megerősítette az erőteljes fikciókat a természetről, amelyek együttműködésben álltak a stabil és virágzó birodalom esztétikai és erkölcsi rendjével. Statius azonban továbbra is kihívta maga ellen Horatiust azzal, hogy erőteljes kapcsolatot teremtett a luxus és a mondén értelemben vett epikureus életstílus között, utóbbit ugyanis beolvasztotta a kiváltságos és jóléti életvitelbe. Statius ${ }^{124}$ Venus és Gyönyör (Voluptas) alakjainak a szerepeltetésével pedig kifejezésre juttatta Vopiscus villájának városi kifinomultságát. Venus és Gyönyör alakjai azonban e szöveg kontextusában filozófiai jelentéssel is rendelkezetek. Venus és Gyönyör ugyanis fontos szimbólumai lettek a helyesen értelmezett élvezetnek, amely egyben mérsékletet és szabadságot is magában foglalt a túlzó vágyakkal szemben. Vopiscus emiatt nem állt annyira távol az epikureus eszménytől. Statius felfogásában ugyanis Vopiscus villája és környezetének kialakítása annak gazdag, pazar és fényüző mivolta ellenére is lelki kiegyensúlyozottságot, békét, kellemességet sugallt. Vopiscus villája, illetve tája a természet és a technika összekapcsolódása révén mentes volt a romboló emberi vágyaktól, sőt: a józan nyugalomnak ${ }^{125}$ adott helyet.

Griffin ${ }^{126}$ vizsgálata azonban arra enged következtetni, hogy Horatius nem olyan egyoldalúan értelmezte a szerénység és jólét kapcsolatát, mint ahogy az Newlands ${ }^{127}$ elemzésében elsőre tűnik. Horatius $^{128}$ az egyik szatírájában egy erősen moralizáló diskurzust hozott létre, miközben egy másik szereplőnek adta át a helyét. Ahelyett, hogy maga demonstrálta volna az egyszerü élet erényeit, Horatius mindezt Ofellus filozófus képzelt alakjának engedte át. Horatius már a szatíra kezdetén

\footnotetext{
${ }^{120}$ NeWLands 2002. 133-136.

${ }^{121}$ Stat. Silv. 1.3.92-93. „,... fronte gravis sanusque nitor luxuque carentes deliciae, ...” (,, itt az öröm józan, s fényüzés nélküli jólét/csillog. ...” Ford. Muraközy Gyula)

${ }^{122}$ NewLands 2002. 137.

${ }^{123}$ Stat. Silv. 1.3.105-110. „Digne Midae Croesique bonis et Perside gaza,/macte bonis animi, cuius stagnantia rura/ debuit et flavis Hermus transcurrere ripis/et limo splendente Tagus. sic docta frequentes/otia, sic omni detectus pectora nube/ finem Nestoreae precor egrediare senectae.” (,, Méltó vagy te Midas, Croesus, perzsák vagyonára -/s boldog a szellemedével! A Hermus kellene fusson/ázó réteden át az aranyszinü folyamágyban,/és ragyogó fövenyü Tagus. Élj e tudós nyugalomban/ hosszan, fellegeit lelkedre a gond ne bocsássa,/s múld felül - óhajom ez - majd jóval a nestori vénkort!" Ford. Muraközy Gyula)

${ }^{124}$ Stat. Silv. 1.3.9-10.

${ }^{125}$ Statius Vopiscus ingatlanát elszigetelt, biztonságos világként alkotta meg, amely távol esett a közélet zűrzavarától. Az ingatlan csendjét nem zavarhatta meg semmilyen nyugtalanság vagy egyéb felkavaró dolog. Mindez szintén utalt Vopiscusnak a filozófiai értelemben vett békéjére és a szenvedélyektől való függetlenségére. Utóbbi bizonyításához pedig Statius számos elemet felhasznált. Például a ház magasztalt hűvössége - amelyet nem bágyasztott el a hőség - metaforikus módon fejezte ki a ház és tulajdonosának belső nyugalmát lásd NEWLANDS 2002. 137-138.

${ }^{126}$ GRIFFIN 1995. 43.

${ }^{127}$ NEWLANDS 2002. 130-136.

${ }^{128}$ Hor. Sat. 2.2.
} 
megállapította a távolságot közte és az egyszerü filozófus között, akinek ,,bölcsessége” csupa morális közhelyből állt. Ez a fajta távolságtartás pedig arra sarkallhatja az olvasókat, hogy merüljön fel bennük némi kétely Ofellus szavainak igazságtartalmát illetőleg. Mindazonáltal vegyék figyelembe őket egy nagyobb és összetettebb erkölcsi és politikai világ kontextusában, amelyben Horatius maga is élt. A vers tulajdonképpen arra tanított, hogy mindkét szélsőséget: a fényűzést és a nyomort egyaránt kerülni kellett, amennyiben az olvasók (akárcsak Horatius) elég szerencsések voltak, hogy rendelkeztek egy kis ingatlannal (pl. Horatius Sabinumban, kb. 40-45 km-re Rómától), ahol az olvasók (ha úgy döntöttek) gyakorolták Ofellus elveit megfelelő korlátok (vagy inkább kompromisszumok) közé helyezett formában. Így értelmezve, Horatius Ofellus alakját nemcsak az erkölcs szemléltetésére használta, hanem egy erkölcsi probléma megállapítására, amelyet nem sikerült megnyugtatóan lezárni.

\section{6. ÖSSZEGZÉS}

Thibodeau ${ }^{129}$ megállapította, hogy a rómaiak felfogásukban két alapkategóriába sorolták a tulajdonos birtokából származó javakat. Ezek szerint létezett a terméshozam (fructus), azaz anyagi többlet, amelyet a gazda a birtok növény- és állatvilágából nyerhetett. Továbbá az esztétikai élvezet (delectatio). Ideális esetben a két alapelv kiegészítette egymást, így az ingatlanon végzett bármilyen változtatás a terméshozam növelése érdekében még vonzóbbá tehette azt. És fordítva: az esztétikai alapokon álló bármely tökéletesítés megemelhette a hasznot anyagi és intellektuális szinten is. Vopiscus villája és a hozzá tartozó tájban fellelhető mesterséges vagy természetesnek ható látványosságok pedig mind ezt szolgálták.

Spencer ${ }^{130}$ gondolatait áttekintve, Statius a római identitás kulcselemét másította meg költészetében. Ez a kulcselem pedig az volt, hogy a római polgár elvárt szerepkörének egy része megegyezett a gazdálkodóéval. Ezt a hagyományt pedig egészen Romulus alakjáig ${ }^{131}$ vissza lehetett vezetni. A természet mesterséges és nem mezőgazdasági jellegü értékei úgy tűnik, Statiusnál leváltak az önellátás, termékenység és a jó kormányzás már ismert hátteréről. A szemlélődő olvasó bárhova is tekintett Statius ${ }^{132}$ vidéki tájképében az élvezet, illetve a vágy az esztétikai látványra és az intellektuális termelésre fókuszálódtak. Domitianusnak a művészet, irodalom, továbbá a vallás iránti, részben hivatalból ${ }^{133}$ történő érdeklődése pedig lehetőséget adott ezekhez a filozófiailag megalapozott és esztétikai értelemben komplex tájképekbe történő ,, kiruccanásokhoz”.

\footnotetext{
${ }^{129}$ Thibodeau 2011. 61-64. A szerző megállapításai Var. $r$. $r$. 1.4.1-2. szöveghelyeire utalnak.

${ }^{130}$ SPENCER 2010. 111-112.

${ }^{131}$ Vö. Col. praef. 17. és Plin. Nat. 18.5-6.

${ }^{132}$ Stat. Silv. 1.3.81-90.

${ }^{133}$ Suet. Dom. 4.; 20. Suetonius szerint Domitianus olyan versenyt hozott létre, amelyen egyszerre képviseltette magát a vallás és az irodalom. Suetonius azonban azt is megjegyezte, hogy a történelmi és költői művekben mégsem mélyedt el igazán. Tacitus pedig azt állította, hogy Domitianus időnként csak színlelt érdeklődést mutatott a tudományok és a költészet iránt lásd Tac. Hist. 86. Martialis és Statius viszont pozitív hangvételű sorokban emlékeztek meg a császár jámborságáról, költői versenyeiről és Róma újjáépítéséről lásd Mart. 4.1.5.; 5.7.1-4.; 5.19.4. és Stat. Silv. 3.5.28-31. Az előbb idézett négy szerző soraiban egyaránt felbukkan a bírálat és a hízelgés. Tény azonban, hogy Domitianus elődeihez hasonlóan egyrészt kötelességből és politikai tőkéje gyarapítása végett, másrészt saját műveltsége okán fordult a hagyományos római valláshoz és az emelkedett kultúrához lásd ADAMIK 2009. 410-411.
} 
Spencer ${ }^{134}$ szerint Statius olvasója megtapasztalhatta a gyönyörködtetés összetett rendszerét. Sejthető, hogy a nagyszerü jólét, amely a versben nem kapcsolódott a villa ingatlanpiaci vagy gazdasági hátteréhez, ennek ellenére létrejött és még meg is szilárdult, ahogy a hozzá tartozó erkölcsök (mores) is. A vers végkicsengése tehát mégsem az, hogy az olvasó egy olyanfajta luxushoz jutott el, amely a fényűzésen kívül mindent feladott, s ami a teljes társadalmat megrontotta. Ez a típusú villa-tájkép azonban nem rendelkezett semmiféle polgári kötelezettséggel sem, amelyet Cicero ${ }^{135}$ vagy Ifjabb Plinius ${ }^{136}$ hangoztattak. De még azokkal az extravagáns és egyben elrettentő allürökkel sem, amelyekkel a lucullusi birtokokról ${ }^{137}$ vagy a nerói Domus Aureáról ${ }^{138}$ szóló leírásokat ellátták. Mindenesetre Statius verse ezt a villát még Rómában is láthatóvá tette, ezzel pedig hirdette a filozófiai tőke láthatatlan javát mint kulturális és társadalmi érték. A domitianusi korszellem támogatta a vallásos jámborságot és a kulturális produktivitást. Statius villa-verse pedig megmutatta, hogy a táj hogyan gyűjthette magába az egyén kiválóságait, vallási képzeteit, érdeklődését, jó ízlését, biztosítva ezeket, hogy a hencegés távol maradjon tőlük.

Statius a költői leleménynek köszönhetően létrehozott a szövegben megjelenő képi reprezentációt: egy irodalmi tájképet. S e textuális tájképben Vopiscus a Gyönyörrel (Voluptas) karöltve kialakított egy lenyügöző villát. A verssorokban leírt tájkép egy olyan átértelmezett környezetet reprezentál, amelynek az alapelemei fellelhetőek voltak a valóságban, sőt még a társadalmi felfogásban bekövetkező változásokra is utaltak. Ami viszont elválasztja ezt az ábrázolásmódot a ,, vegytiszta” valóságtól az a sorok mellől előbújó eszmei vetület, prekoncepció, intertextualitás, amelyek több értelmezési lehetőséget is felkínálnak az olvasóknak.

Marzano ${ }^{139}$ alapján egy ilyen irodalmi koncepcióként értékelendő, hogy a köztárság végén élő Varro ${ }^{140}$ számára a villában esztétikusabb látványnak számítottak az igényesen kialakított gyümölcstárolók (aporothecae), semmint a királyi palotákat utánzó udvarházak, amelyek mügyüjteményekkel voltak felékítve. A Kr. u. 1-2. század fordulóján azonban annak ellenére, hogy Statius ${ }^{141}$ Alkinoos ligetéhez hasonlította Vopiscus villájának gyümölcsösét, vagy Ifjabb Plinius ${ }^{142}$ említést tett a haszonnövényekről villájában és a környező területeken, utóbbiak csupán a ,,falusi díszlet”, szerepét töltötték be. Statius villa-verse pedig a fentebb említett változás erkölcsi legitimálását vitte véghez, amellyel Ifjabb Plinius mellett lírai eszközökkel hozta létre az otium-villának a valósághoz szerves módon kapcsolódó, mégis eszmei mondanivalókkal telített irodalmi konstrukcióját.

\footnotetext{
${ }^{134}$ SPENCER 2010. 112-113.

${ }^{135}$ Cic. Sen. 15-18. Cicero egyrészt Idősebb Catót tette meg dialógusa főszereplőjévé, akin keresztül további tekintélyeket idézett meg a római múltból. Hangsúlyozta, hogy ezek a személyek a politikai és katonai pályafutásuk mellett is egyszerűségben, a földművelésnek éltek. Mindezt filozófiailag is megalapozta, amikor egymás mellé állította a bölcsességet a mezőgazdasággal.

${ }^{136}$ Plin. Ep. 4.23.3. Ifjabb Plinius úgy vélekedett, hogy a római polgárnak élete első kétharmadát a politikai, hivatali vagy katonai közügyeknek kellett, hogy szentelje, amely tevékenységek a városhoz kötődtek. A fennmaradó egyharmad részt pedig a tisztes, nyugalmas öregkor töltötte ki, amelynek ideális terepe lehetett a vidéki villa.

${ }^{137}$ Plut. Luc. 39.

${ }^{138}$ Tac. Ann. 15.42 .

${ }^{139}$ MARZANO 2007. 87.

${ }^{140}$ Var. $r . r .1 .59 .2$.

${ }^{141}$ Stat. Silv. 1.3.81-82.

${ }^{142}$ Plin. Ep. 5.6.35.
} 


\section{FelHaSZnÁlt IROdALOM}

\section{Források}

Arist. Poet. $=$ Arisztotelész: Poétika . Ford., jegyz. Sarkady János. Budapest, 1974, Magyar Helikon.

Cato Agr. = Cato, Marcus: A földmüvelésröl. Latinul és magyarul. Ford., jegyz. Kun József. Bev. Maróti Egon. Budapest, 1966, Akadémiai Kiadó.

Calp. Ecl. $=$ Calpurnius, Titus: Eclogae. http://penelope.uchicago.edu/Thayer/E/Roman/Texts/Calpurnius Siculus/home.html Hozzáférés: 2017. 09. 13. 23:09

Catul. = Catullus, Caius: Catullus versei. Catulli Veronensis Liber. Szöveget gond., bev., jegyz. Adamik Tamás. Budapest, 1998, Tankönyvkiadó.

Cic. De or. $=$ Cicero, Marcus: De Oratore. http://www.perseus.tufts.edu/hopper/text?doc=Perseus: text:1999.02.0120. Hozzáférés: 2018. 01. 20. 12:10

Cic. De rep. $=$ Cicero, Marcus: De Republica . http://www.perseus.tufts.edu/hopper/text?doc=Perseus: text:2007.01.0031. Hozzáférés: 2018. 01. 20. 11:54

Cic. Fam. $=$ Cicero in Twenty-Eight Volumes. XXV. The Letters to his Friends. I. With an English Translation by W. Glynn Williams. Cambridge (Massachusetts) - London, 1979, Harvard University Press - William Heinemann Ltd.

Cic. Leg. = Cicero, Marcus: De Legibus. http://www.perseus.tufts.edu/hopper/text?doc=Cic.\%20Leg. Hozzáférés: 2018. 02. 21. 14:11

Cic. Rosc. Am. = Cicero, Marcus: Pro Sextius Roscius. http://www.perseus.tufts.edu/hopper/text?doc= Perseus:text:1999.02.0010. Hozzáférés: 2018. 01. 20. 12:12

Cic. Sen. $=$ Cicero in Twenty-Eight Volumes. XX. De Senectute. De Amicitia. De Divinatione. Translation by William Armistead Falconer. Cambridge (Massachusetts) - London, 1979, Harvard University Press - William Heinemann Ltd.

Col. = L. Iuni Moderati Columellae Res Rustica. Incerti auctoris Liber de arboribus. Szerk. R. H. Rodgers. Oxford, 2010, Oxford University Press.

Gel. = Gellius, Aulus: Noctes Atticae. http://penelope.uchicago.edu/Thayer/E/Roman/Texts/Gellius/ home.html. Hozzáférés: 2018. 02. 19. 23:55

Hor. Ep., Od., Sat. = Horatius, Quintus: Epistulae, Odes, Saturae. https://www.hs-augsburg.de/ harsch/ Chronologia/Lsante01/Horatius/hor_intr.html. Hozzáférés: 2018. 01. 20. 11:01

Horatius összes művei Bede Anna fordításában. Budapest, 1989, Európa Könyvkiadó.

Juv. = Juvenalis, Julius: Saturae. https://www.hs-augsburg.de/ harsch/Chronologia/Lspost02/ Iuvenalis/iuv_sa00.html. Hozzáférés: 2018. 01. 20. 12:41

Liv. = Livius, Titus: $A b$ Urbe Condita Libri 35-38. http://www.perseus.tufts.edu/hopper/text?doc= Perseus:text:1999.02.0178. Hozzáférés: 2018. 01. 20. 12:44

Mart. = Martialis, Marcus: Epigrammaton Libri. https://archive.org/details/mvaleriimartial01 friegoog. Hozzáférés: 2018. 04. 09. 18:21 
Pers. $=$ Persius, Aulus: Saturae. http://www.perseus.tufts.edu/hopper/text?doc=Perseus: text:2008.01.0497. Hozzáférés: 2018. 01. 20. 12:19

Petr. Sat. $=$ Petronius, Arbiter: Satyricon . http://www.perseus.tufts.edu/hopper/text?doc=Perseus: text:2007.01.0001. Hozzáférés: 2018. 01. 20. 12:15

Plin. Ep. = Plinius, Caius: Epistulae. https://www.hs-augsburg.de/ harsch/Chronologia/Lspost02/ PliniusMinor/pli_ep00.html. Hozzáférés: 2018. 01. 20. 11:05

Plin. Nat. = Plinius Maior: Naturalis Historia . http://penelope.uchicago.edu/Thayer/e/roman/texts/ pliny_the_elder/home.html. Hozzáférés: 2018.01.20.11:06

Plut. Luc. = Plutarkhosz: Lucullus. In Párhuzamos életrajzok. I. Ford. Máthé Elek. Budapest, 2005, Osiris Kiadó.

Prop. $=$ Propertius, Sextus: Elegiae . http://www.perseus.tufts.edu/hopper/text?doc=Perseus: text:2008.01.0494. Hozzáférés: 2018. 01. 20. 11:07

Quint. Inst. = Quintilianus, Marcus: Institutionis Oratoriae Libri Duodecim. https://www.hs-augsburg.de/ $\sim$ harsch/Chronologia/Lspost01/Quintilianus/qui_in00.html. Hozzáférés: 2018. 01. 20. 12:24

Rhet. Her. = Cornificius: De Ratione Dicendi ad C. Herennium libri IV. https://www.hs-augsburg.de/ $\sim$ harsch/Chronologia/Lsante01/AdHerennium/rhe_h000.html. Hozzáférés: 2018. 01. 20. 12:33

Sen. Ep. $=$ Seneca, Lucius: Ad Lucilium Epistulae Morales. http://www.perseus.tufts.edu/hopper/ text?doc=Perseus:text:2007.01.0080. Hozzáférés: 2018. 01. 20. 11:09

Suet. Aug., Dom., Vesp. = Suetonius, Caius: Divus Augustus. Domitianus. Divus Vespasianus. http://penelope.uchicago.edu/Thayer/l/roman/texts/suetonius/12Caesars/Augustus*.html. Hozzáférés: 2018. 01. 20. 11:15

http://penelope.uchicago.edu/Thayer/L/Roman/Texts/Suetonius/12Caesars/Domitian*.html. Hozzáférés: 2018. 01. 20. 11:56

http://penelope.uchicago.edu/Thayer/L/Roman/Texts/Suetonius/12Caesars/Vespasian*.html. Hozzáférés: 2018. 01. 20. 11:57

Stat. Achill. $=$ Statius, Publius: Achilleis. http://www.perseus.tufts.edu/hopper/text?doc=Perseus: text:2008.01.0500. Hozzáférés: 2018. 01. 20. 11:59

Stat. Silv. = Statius, Publius: Erdők. Latinul és magyarul. Ford., jegyz. Muraközy Gyula. Budapest, 1979, Akadémiai Kiadó.

Tac. Ann. $=$ Tacitus, Publius: Annales. http://www.perseus.tufts.edu/hopper/text?doc=Perseus: text:1999.02.0077. Hozzáférés: 2018. 01. 20. 11:22

Tac. Hist. $=$ Tacitus, Publius: Historiae. http://www.perseus.tufts.edu/hopper/text?doc=Perseus: text:1999.02.0079. Hozzáférés: 2018. 01. 20. 11:28

Tib. = Tibullus, Albius: Elegiae. http://www.perseus.tufts.edu/hopper/text?doc=Perseus: text:2008.01.0507. Hozzáférés: 2018. 01. 20. 11:17

Var. $r . r$ = Varro, Marcus: A mezőgazdaságról. Latinul és magyarul. Ford., jegyz. Kun József. Bev. Maróti Egon. Budapest, 1971, Akadémiai Kiadó.

Verg. $G$. = Vergilius, Publius: Georgicon . http://www.perseus.tufts.edu/hopper/text?doc=Perseus: text:1999.02.0059. Hozzáférés: 2018. 01. 20. 11:18 


\section{Szakirodalom}

ACÉL Zsolt (2012): Contextus és corpus. A korpusz-metafora kialakulása és Cicero könyvgyűjteményei. Ókor 11. évf. 4. sz. 43-50.

Adamik Tamás (2009): Római irodalom. A kezdetektől a Nyugatrómai Birodalom bukásáig. Pozsony, Kalligram Kiadó.

Albrecht, Michael von (2004): A római irodalom története. II. Ford. Tar Ibolya. Budapest, Balassi Kiadó.

Alföldy GÉZA (2002): Római társadalomtörténet. Budapest, Osiris Kiadó.

BENCZE IlonA (2017): Egy hullámzó világ képei. Reális, irreális, szürreális tájkép a korai római császárkorban. Ókor 16. évf. 1. sz. 65-75.

BorzSÁK IsTVÁN (1969): Horatius: Epistulae. Szöveg gond., bev., jegyz.. Borzsák István. Budapest, Tankönyvkiadó.

Caro, Stefano De (2005): Oplontis. In Marisa Ranieri Panetta (szerk.): Pompeji: Az eltemetett város történelme, mindennapi élete és müvészete. Pécs, Alexandra Kiadó. 373-400.

Drougou, Stella (2001): s.v. Polybios. In Der neue Pauly. Enzyklopädie der Antike. Altertum. Band 10. Pol-Sal. Herausgegeben von Hubert Cancik und Helmuth Schneider. Stuttgart - Weimar, Verlag J. B. Metzler. 41-42.

Griffin, Dustin (1995): Satire. A Critical Reintroduction. Lexington, The University Press of Kentucky.

HegYi GyöRgy (1979): Statius, a költő, akit Apollo és Domitianus ihletett. In Publius Papinius Statius: Erdők. Latinul és magyarul. Ford., jegyz. Muraközy Gyula. Bev. Hegyi György. Budapest, Akadémiai Kiadó. 5-57.

Höcker, Cristoph (2002): s.v. Villa. In Der neue Pauly. Enzyklopädie der Antike. Altertum. Band 12/2. Herausgeben von Huber Cancik und Helmuth Schneider. Stuttgart, J. B. Metzler Verlag. 210-221.

Humphrey, John H. (1986): Roman Circuses. Arenas for Chariot Racing. Berkeley - Los Angeles, University of California Press.

Inwood, Brad (2000): s.v. Panaitios. In: Der neue Pauly. Enzyklopädie der Antike. Altertum. Band 9. Or-Poi. Herausgegeben von Hubert Cancik und Helmuth Schneider. Stuttgart - Weimar, Verlag J. B. Metzler. 226-228.

Lotman, Jurij (2001): Kultúra és robbanás. Ford. Szűcs Teri. Pannonica Kiadó.

Marzano, Annalisa (2007): Roman Villas in Central Italy. A Social and Economic History. Leiden, Brill.

Mielsch, Harald (1987): Die römische Villa. Architektur und Lebensform. München, Verlag C. H. Beck.

Mitchell, Thomas William John (2005): Mi a kép? Ford. Szécsényi Endre. In Kárpáti Eszter (szerk.): Szöveggyüjtemény a szemiotika tanulmányozásához. Budapest, Aula Kiadó. 117-155. 
MNL (1977): s.v. átadás, átvétel. In Ortutay Gyula (főszerk.): Magyar Néprajzi Lexikon. I. Budapest, Akadémiai Kiadó. 162-163., 170-171.

MYERS, SARA KAREN (2015): Statius on Invocation and Inspiration. In Newlands, Carol Elizabeth Gervais, Kyle - Dominik, William John (szerk.): Brill's Companion to Statius. Leiden, Brill. 31-54. NAGYILLÉS JÁNOS (2012): Képzőművészet és epikus költészet: a mimésis mimésise? In Gesztelyi Tamás (szerk.): Irodalom és képzömüvészet a korai császárkorban. Debrecen, Debreceni Egyetemi Kiadó. 37-63.

Nauta, RuUrd Robisn (2002): Poetry for Patrons. Literary Communication in the Age of Domitian. Boston - Leiden - Köln, Brill.

Newlands, Carole Elizabeth (2002): Statius's Silvae and the Poetics of Empire. Cambridge, Cambridge University Press.

Newlands, Carole elizabeth - Gervais, Kyle - Dominik, William John (2015): Reading Statius. In Newlands, Carol Elizabeth - Gervais, Kyle - Dominik, William John (eds.): Brill's Companion to Statius. Leiden, Brill. 3-31.

RIPOLL, FranÇOIS (2015): Statius and Silius Italicus. In Newlands, Carol Elizabeth - Gervais, Kyle Dominik, William John (eds.): Brill's Companion to Statius. Leiden, Brill. 425-444.

Roman, Luke (2014): Poetic Autonomy in Ancient Rome. Oxford. Oxford University Press.

Roman, LuKe (2015): Statius and Martial: Post-vatic Self-fashioning in Flavian Rome. In Newlands, Carol Elizabeth - Gervais, Kyle - Dominik, William John (eds.): Brill's Companion to Statius. Leiden, Brill. 444-465.

RÜHL, MeIKe (2015): Creating the Distinguished Addresse: Literary Patronage in the Works of Statius. In Newlands, Carol Elizabeth - Gervais, Kyle - Dominik, William John (eds.): Brill's Companion to Statius. Leiden, Brill. 91-106.

SPencer, Diana (2010): Roman Landscape: Culture and Identity. New York, Cambridge University Press.

SzeKEREs CsiLla (2012): Valóság és illúzió. In Gesztelyi Tamás (szerk.): Irodalom és képzömüvészet a korai császárkorban. Debrecen, Debreceni Egyetemi Kiadó. 9-21.

TÁNCZOS VILMOS (2011): A népi kultúra általános jellemzöi. https://anczosvilmos.files.wordpress.com/ 2011/09/01-alapfogalmak1.pdf. Hozzáférés: 2017. 10. 17. 17:44

Thibodeau, Philip (2011): Playing the Farmer. Representations of Rural Life in Vergil's Georgigcs. Berkeley - Los Angeles, University of California Press.

Vessey, David T. (2001): s.v. P. Papinius S. In Der neue Pauly. Enzyklopädie der Antike. Altertum. Band 11. Sam-Tal. Herausgegeben von Hubert Cancik und Helmuth Schneider. Stuttgart - Weimar, J. B. Metzler Verlag. 925-928. 